\title{
The Upper Cretaceous Guaynopa IOCG and Guaynopita porphyry copper deposits, Chihuahua, Mexico
}

Antoni Camprubí ${ }^{\mathrm{a}, *}$, Eduardo González-Partida ${ }^{\mathrm{b}}$, Margarita López-Martínez ${ }^{\mathrm{c}}$, Alexander Iriondo $^{\mathrm{b}, \mathrm{d}}$, Pura Alfonso ${ }^{\mathrm{e}}$, Edith Cienfuegos-Alvarado ${ }^{\mathrm{a}}$, Eric Gutiérrez-Armendáriz ${ }^{\mathrm{f}}$, Pedro Morales-Puente $^{\mathrm{a}}$, Carles Canet ${ }^{\mathrm{g}}$, Luis González-Ruiz ${ }^{\mathrm{h}}$

${ }^{a}$ Instituto de Geología, Universidad Nacional Autónoma de México, Ciudad Universitaria, 04510 México, D.F., Mexico

${ }^{b}$ Centro de Geociencias, Universidad Nacional Autónoma de México, Boulevard Juriquilla 3001, 76230 Juriquilla, Querétaro, Mexico

${ }^{c}$ Centro de Investigación Científica y Estudios Superiores de Ensenada, Carretera Tijuana-Ensenada km. 107, 22860 Ensenada, Baja California, Mexico

${ }^{d}$ Department of Geological Sciences, Jackson School of Geosciences, The University of Texas at Austin, Austin, TX 78712, USA

e Departament d'Enginyeria Minera $i$ Recursos Naturals, Universitat Politècnica de Catalunya, Av. de les Bases de Manresa 61-73, 08242 Manresa, Catalonia, Spain

${ }^{f}$ Programa de Posgrado en Ciencias de la Tierra, Universidad Nacional Autónoma de México, Boulevard Juriquilla 3001, 76230 Juriquilla, Querétaro, Mexico

${ }^{g}$ Instituto de Geofísica, Universidad Nacional Autónoma de México, Ciudad Universitaria, 04510 México, D.F., Mexico

${ }^{h}$ Geologia Minería y Consultoría, Cipreses 104, Fraccionamiento Jurica, 76100 Santiago de Querétaro, Querétaro, Mexico

* corresponding author: camprubitaga@gmail.com 


\section{ABSTRACT}

The Guaynopa and Guaynopita mineralized areas in central-western Chihuahua are conterminous sets of ore deposits that formed in association with gabbroic and granitic intrusions that correspond to the Lower Volcanic Complex of the Sierra Madre Occidental silicic large igneous province. The Guaynopa IOCG deposit consists of (1) early iron oxide-copper-gold mantos accompanied by potassic (fuchsite, biotite and potassium feldspar) and/or calcic-sodic alteration (tremolite-actinolite) and hosted by marmorized limestones near the contact with intrusive granites, (2) later copper-rich stockworks and gold disseminations, and (3) late gold- and copper-rich quartz-calcite veins. Mantos contain most of the copper and gold ores in this deposit, and their hypogene mineralogy consists of magnetite, fuchsite, chalcopyrite, Ag-rich gold, cuprite, and late hematite. The Guaynopita porphyry copper deposit consists mainly of stockworks within potassic alteration zones, and includes ancillary sulfide copper- and lead-rich skarn deposits. Microthermometric studies of fluid inclusions were carried out on most mineral associations of the Guaynopa IOCG and in the Guaynopita porphyry copper deposits. In IOCG mantos, temperatures of homogenization (Th) in calcite and quartz vary between $152^{\circ}$ and $310^{\circ} \mathrm{C}$, and apparent salinities between 10.7 and 24.2 wt.\% $\mathrm{NaCl}$ equiv. In IOCG veins, Th in quartz vary between $310^{\circ}$ and $400{ }^{\circ} \mathrm{C}$, and apparent salinities between 11.1 and $21.0 \mathrm{wt} . \% \mathrm{NaCl}$ equiv. In IOCG stockworks, Th in tremolite vary between $330^{\circ}$ and $410{ }^{\circ} \mathrm{C}$, and the apparent salinity is $16.0 \mathrm{wt} \% \mathrm{NaCl}$ equiv. In porphyry-copper stockworks, Th in quartz vary between $205^{\circ}$ and $448{ }^{\circ} \mathrm{C}$, and apparent salinities between 8.1 and 21.3 wt.\% $\mathrm{NaCl}$ equiv. $\delta^{34} \mathrm{~S}$ values for sulfides (mostly chalcopyrite) in IOCG associations range between -15.1 and $7.0 \%$ in mantos, between -3.7 and $-0.2 \%$ in veins, and between -1.6 and $0.2 \%$ in stockworks. $\delta 13 \mathrm{CVPDB}$ values from calcite in IOCG mantos range between -5.22 and $3.45 \%$, and $\delta^{18}$ OVSMOW values between 9.61 and $17.23 \%$, which correspond to the interaction ofmagmatic fluidswith host limestones at a broad range of temperatures and water to rock volumeratios. Likely ore-formation processes are isothermal mixing, conductive cooling, and boiling. In the case of the Guaynopita porphyry copper deposit, similar possible magmatic-dominated fluids underwent progressive dilution and cooling with time, with the occurrence of boiling at some extent. 
New geochronological data from hydrothermal minerals and host rocks for these deposits suggest a minimum $\sim 14$ m.yr. span of conjoined magmatic and hydrothermal activity: biotite and chromian muscovite (fuchsite) from mantos at the Guaynopa IOCG deposits yielded ${ }^{40} \mathrm{Ar} /{ }^{39} \mathrm{Ar}$ plateau ages at $98.12 \pm 0.37$ and $95.42 \pm 0.71 \mathrm{Ma}$ (Cenomanian), respectively, whereas $\mathrm{U}-\mathrm{Pb}$ dating in zircons from diorite and granodiorite host intrusives, and a potassic alteration assemblage at Guaynopita yielded ages at $92.4 \pm 0.5 \mathrm{Ma}, 89.1 \pm 0.7$

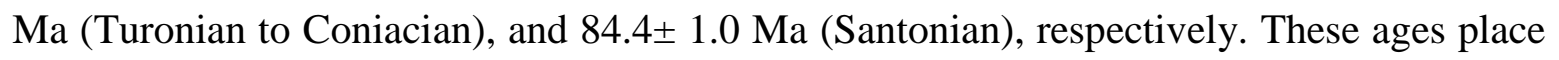
the Guaynopa-Guaynopita ensemble within the Mesozoic metallogenic provinces and epochs in northwestern Mexico. Unlike the majority of Mesozoic generic magmatichydrothermal iron oxide deposits in Mexico, Guaynopa in Chihuahua and Cerro del Oro in Sonora formed at a distal position fromthe paleo-Pacific margin ( 500kminland) and therefore it cannot be ascribed to a general intra-arc "Coastal Andes Cordillera-type" tectonomagmatic setting. Therefore, this regionmay constitute a part of a previously unnoticedmetallogenetic region, and petrogenetic studies should follow in order to properly evaluate the hypothetical possibility for a back-arc setting there during the Late Cretaceous.

\section{Introduction}

The Guaynopa and Guaynopita deposits are located in the border between the Sierra Madre Occidental and the Basin and Range province, with large Mesozoic NW-SE fault zones disrupted by NE-SW, and occasionally E-W faults. Such structural features can be attributed to Cenozoic extensional events. The local sedimentary country rocks (Fig. 1) constitute a mostly Early Cretaceous sequence of carbonate and fine-grained clastic rocks of the Agua Salada, Lampazos and Los Picachos formations. The latter formation overlies unconformably the former two. Pubellier (1987) described twoAlbian sedimentary sequences: the lower sequence consists of argillaceous limestones and shales, and the upper consists of limestones and dolostones. Monreal and Longoria (2000a,b), based on fossil content, proposed a Lower Aptian age for the Agua Salada Formation, an Upper Aptian to Middle Albian age for the Lampazos Formation, and aMiddle toUpper Albian for the Los Picachos Formation. The Lampazos Formation is composed by dark gray thinly bedded limestones alternating with shales and sandstones. The microfauna associations within it, 
comprising bentonic and planctonic foraminifera, calpionelids, ostracoda and radiolaria, indicate depositional environments from external neritic to pelagic marine (Monreal and Longoria, 2000a,b).

The above sedimentary sequences were intruded by granitic rocks that belong to the igneous suite of the Lower Volcanic Complex (Sierra Madre Occidental silicic large igneous province, or SLIP; see Ferrari et al., 2005, 2007), and developed contact marmorization and seldom contact skarn associations. The iron oxide-copper-gold deposits at Guaynopa and the porphyry-type deposits at Guaynopita are associated with such intrusives (Fig. 1), which are essentially gabbros and granodiorites, respectively. During the Eocene were also emplaced andesite porphyry dikes, as well as rhyolitic tuffs, dikes and ignimbrites, all of them ascribed to the Upper Volcanic Supergroup (Sierra Madre Occidental SLIP).

Western Mexico, especially the northern part of this region, is well known to contain numerous metalliferous porphyry-type deposits, which started forming alongside skarn deposits during the Upper Cretaceous in association with the Sierra Madre Occidental SLIP (Valencia-Moreno et al., 2006, 2007; Camprubí, 2013). Then, the Guaynopita deposit constitutes a part of the Upper Cretaceous metalliferous porphyry-type belt that extends along the paleo-Pacific continental margin (Camprubí, 2013). However, no metallogeny for the Upper Cretaceous in Mexico has ever been formally described for magmatichydrothermal iron oxide (MHIO) deposits that formed several hundreds of kilometers inland. Such is the case of the deposits of Guaynopa in Chihuahua or Cerro del Oro in Sonora. The occurrence of MHIO deposits in such location raises the possibility that they may constitute a harbinger sign of a relevant tectonomagmatic and metallogenic event distally to the paleo-Pacific margin, previously unheard of.

\section{Ore deposits}

\subsection{Cuale, Jalisco}

Preliminary surveys in the Guaynopa deposit (González-Partida et al., 2011) indicate that there are four styles of magmatichydrothermal iron oxide (MHIO) mineralization (Fig. 
1): early iron oxide-rich mantos (Fig. 2a,b), later copper-rich stockworks, gold disseminations, and late quartz and calcite-rich veins (Fig. 2c). Mantos (Tres Amigos, Cinco de Mayo, Chalas, and Tazcate) average $2 \mathrm{~m}$ in thickness, and are located preferentially between the marmorized limestones and the intrusive rocks. Their hypogene mineralogy consists of magnetite, chromian muscovite (fuchsite), chalcopyrite, pyrite, sphalerite, Ag-rich gold, cuprite, K-feldspar, some tremolite- actinolite and kaolinite, besides malachite and azurite as supergene minerals. Some hypogenic replacement of magnetite by hematite (martitization) is common in mantos at variable degrees. Quartz and calcite are common gangue minerals in any ore-bearing assemblages.

The Tres Amigos manto averages $11.84 \mathrm{~g} / \mathrm{t} \mathrm{Au}, 14.88 \mathrm{~g} / \mathrm{t} \mathrm{Ag}$, and $1.54 \% \mathrm{Cu}$. Highgrade quartz-gold veins strike nearly E-W or NE-SW (Fig. 1), are visibly up to $800 \mathrm{~m}$ long, $600 \mathrm{~m}$ deep, and average $0.80 \mathrm{~m}$ thick (La Libertad vein), and are hosted by the limestone sequence and the highly altered dioritic intrusive. Average grades for the La Libertad vein are $44.8 \mathrm{~g} / \mathrm{t} \mathrm{Au}, 32.8 \mathrm{~g} / \mathrm{t} \mathrm{Ag}$, and $0.13 \% \mathrm{Cu}$.

Fuchsite, biotite and K-feldspar constitute potassic alteration assemblages. Tremoliteactinolite, and kaolinite are the key minerals that constitute calcic-sodic, and argillic alteration assemblages, respectively. Propylitic alteration is the most conspicuous alteration assemblage and consists of chlorite, calcite and epidote. Pervasive potassic alteration was identified on most diorite outcrops and is spatially associated with mantos. Ferromagmesian minerals in the diorite, such as hornblende, are typically altered to chlorite. Strongly pervasive hypogene argillic alteration appears to be associated exclusively with widespread stockworks and gold disseminations (Fig. 2c). The former are conspicuous by the Yuta gulch as an array of veinlets up to $2 \mathrm{~cm}$ thick and consist of quartz, copper sulfides and gold. In the La Escondida-El Muerto area, gold is found both in stockworks and disseminated in argillic alteration assemblages that were developed in the host diorite, which grade up to $30.05 \mathrm{~g} / \mathrm{t} \mathrm{Au}$.

\subsection{The Guaynopita porphyry copper deposit}

The Guaynopita porphyry copper deposit (Fig. 1; González-Partida et al., 2011) crops out in an area of $\sim 5 \mathrm{~km} 2$ about $5 \mathrm{~km}$ south of the IOCG Guaynopa deposits. It consists of 
quartz veinlets (Fig. 2d) that occasionally form stockworks in the intrusive rocks (Fig. 2e). Preliminary surveys indicate that these ore-bearing associations grade between 0.1 and $2 \%$ $\mathrm{Cu}$, and are coupled with anomalous $\mathrm{Au}, \mathrm{Ag}$ and Mo contents. When hosted by the carbonate rocks, the mineralization is essentially found as quartz veins, up to $0.5 \mathrm{~m}$ thick and 150 to $200 \mathrm{~m}$ long. The most prominent stockwork zones are named La Leona and La Esmeralda (Fig. 1).

The hypogene mineralogy of the ores consists of quartz, potassium feldspar, chalcopyrite, chalcocite, pyrite and sphalerite plus widespread supergene azurite, malachite (Fig. 2e) and native copper. The veinlets are zoned and showpotassiumfeldspar on the borders (Fig. 2d), whereas quartz and copper minerals occur in the veinlet cores. Only potassic alteration is pervasive in the mineralized area, as observed in the present state of exploration endeavor, and occurs in association with the highest metal grades. Propylitic alteration occurs peripherally to potassic alteration zones.

The timing of both the Guaynopita porphyry copper-type and the Guaynopa IOCG deposit and their 'parental' intrusives is explored in this paper in the next sections. Sulfide skarn deposits are also present, and consist of up to $\sim 2 \mathrm{~m}$ thick mantos (Morelos manto) that are rich in chalcopyrite and pyrrhotite, with azurite and malachite as supergene minerals. Other smaller mantos (Fig. 1) are found detached from either skarns or stockworks; one of them is constituted by manganese oxi-hydroxides and grades up to 2.5 $\mathrm{kg} / \mathrm{t} \mathrm{Ag}$, and some are constituted by massive galena as the main mineral (i.e. the Plomosas manto). Although these mantos have not been identified to correlate in any way with the porphyry copper and sulfide skarn mineralizations at Guaynopita or with the IOCG deposits at Guaynopa, the likeliest possible genetic association of such mantos would be with the sulfide skarn mineralizations.

\section{Fluid inclusion studies}

Preliminary fluid inclusion petrographic and microthermometric studies were carried out in fourteen samples (calcite, quartz and tremolite), comprising mantos (Tres Amigos and Las Chalas), the La Libertad vein, and La Escondida-El Muerto stockwork zone, being all of them part of the IOCG deposits (Guaynopa), and the La Esperanza stockwork zone of 
the porphyry copper deposit (Guaynopita). The studied samples were doubly polished sections (100 to $150 \mu \mathrm{m}$ thick). Primary, pseudosecondary and secondary inclusions were found. The analyzed inclusions are liquid-rich (their degree of filling varies from 0.60 to 0.90; Fig. 3-A,B) and therefore the inclusions homogenized systematically into a liquid phase, contain no daughter crystals, and their sizes range from 5 to $25 \mu \mathrm{m}$. $\mathrm{CO}_{2}$-bearing inclusions are common in the IOCG deposits and are most conspicuous in the La Libertad vein as "double bubbles", with liquid $\mathrm{CO}_{2}$ (Fig. 3-C). This vein also shows aqueous liquidrich and vapor-rich inclusions coexisting in individual fluid inclusion assemblages (or, at least, inhomogeneous degrees of filling within each FIA), which is interpreted as likely evidence for boiling (Fig. 3-B for Guaynopa and 3-F for Guaynopita). Only a few inclusions contain daughterminerals, amongwhich halite is the only recognizable phase (Fig. 3-E). Primary fluid inclusions occur in growth zones parallel to crystal faces (Fig. 3D), or occur as solitary inclusions or isolated groups of inclusions lacking healed fractures (where growth zones could not be identified). Pseudosecondary inclusions occur along planes crosscut by later growth zones.Many primary and pseudosecondary inclusions showed evidence of necking and some leakage. Necking is manifested in groups of fluid inclusions resulting in a wide range of vapor to liquid ratios (degree of filling). These have been differentiated from fluid inclusion assemblages (FIAs) that recorded boiling using the criterion that, although both have similar variations in degree of filling, inclusions due to necking have relatively irregular shapes with elongated terminations that point to similar terminations in other inclusions. For this paper, only primary and pseudosecondary inclusionswere analyzed. All liquid-rich inclusions homogenized into a liquid phase, none did so into a supercritic fluid. Microthermometric studies were carried out on a Linkam THMSG600 heating-freezing stage. Calibration runs show that the measurements are accurate to $\pm 0.2{ }^{\circ} \mathrm{C}$ for lowtemperature measurements, and to $\pm 2{ }^{\circ} \mathrm{C}$ for high-temperature measurements. Salinitieswere calculated by using freezing point depression temperatures in the SALTY software by Bodnar et al. (1989) and Bodnar (1993). The obtained microthermometric data are displayed in Table 1 and Fig. 4.

Inclusion fluids in IOCG mineralizations at Guaynopa yielded the following data ranges: 
- temperatures of homogenization between $152^{\circ}$ and $310{ }^{\circ} \mathrm{C}$, and ice melting temperatures between $-22.8^{\circ}$ and $-7.2^{\circ} \mathrm{C}$ (calculated salinities range between 10.7 and 24.2 wt.\% $\mathrm{NaCl}$ equiv.) in mantos; both temperature of homogenization and salinity data are higher in the Chalas manto than in the Tres Amigos manto, as they span from $171^{\circ}$ to $310^{\circ} \mathrm{C}$ and from 23.0 to $24.2 \mathrm{wt} . \% \mathrm{NaCl}$ equiv. in the former, and from $152^{\circ}$ to $258{ }^{\circ} \mathrm{C}$ and from 10.7 to $23.7 \mathrm{wt} . \% \mathrm{NaCl}$ equiv. in the latter;

- temperatures of homogenization between $310^{\circ}$ and $400{ }^{\circ} \mathrm{C}$, temperatures of homogenization of $\mathrm{CO}_{2}$ between $31.2^{\circ}$ and $33.5^{\circ} \mathrm{C}$, and ice melting temperatures between $-18.1^{\circ}$ and $-7.5^{\circ} \mathrm{C}$ (calculated salinities range between 11.1 and $21.0 \mathrm{wt} \%$ $\mathrm{NaCl}$ equiv.) in veins;

- temperatures of homogenization between $330^{\circ}$ and $410{ }^{\circ} \mathrm{C}$, and ice melting temperatures at $-12.1^{\circ} \mathrm{C}$ (calculated salinity of $16.0 \mathrm{wt} . \% \mathrm{NaCl}$ equiv.) in stockworks.

Inclusion fluids in porphyry-copper stockworks at Guaynopita yielded temperatures of homogenization that range between $205^{\circ}$ and $448^{\circ} \mathrm{C}$, average pressures of homogenization up to 272 bar, and ice melting temperatures between $-18.5^{\circ}$ and $-5.2{ }^{\circ} \mathrm{C}$ (calculated salinities range between 8.1 and 21.3 wt.\% $\mathrm{NaCl}$ equiv.). All the different mineral associations from Guaynopa and Guaynopita that were analyzed in fluid inclusion studies contain numerous fluid inclusion associations (FIA); within each FIA, the variation ranges of temperatures of homogenization did not span more than $20{ }^{\circ} \mathrm{C}$. Then, relatively wide ranges of variation of such temperatures in each mineral association are more likely to be the effect of actual geological mechanisms (dilution, boiling, conductive cooling, isothermal mixing; Fig. 4) related to mineral precipitation than the consequence of posttrapping phenomena or to mixed data from different FIAs.

\section{Isotope studies}

\subsection{Sulfur}

Sulfur isotope compositions were analyzed in 46 pure separates of chalcopyrite, pyrite and sphalerite from manto (Tres Amigos, Tazcate, Cinco de Mayo, and Chalas), vein (La 
Libertad) and stockwork (La Escondida) associations from the Guaynopa area. The sulfide separates from these deposits were obtained by hand picking under the microscope from samples previously studied in polished section. The sulfides were combusted with $\mathrm{CuO}$ at $1000{ }^{\circ} \mathrm{C}$ to release $\mathrm{SO}$. The $\mathrm{SO}_{2}$ was analyzed using a Finnigan continuous flow

spectrometer in the Serveis Cientificotècnics of the Universitat de Barcelona (Spain). Precision of the analyses is better than $\pm 0.2 \%$. Sulfur isotope composition is expressed as the delta permil notation with respect to the Canyon Diablo Troilite (CDT) standard. The obtained $\delta^{34} \mathrm{~S}$ data are displayed in Table 2 and Fig. 5 .

The $\delta^{34} \mathrm{~S}$ data for the mantos are distributed in wide range of variation, from -15.1 to 7.0\%. The Tres Amigos manto records the widest variation, between -15.1 and $-0.1 \%$ with a broadly bimodal distribution towards either extreme values, whereas the other mantos display much shorter ranges of variation: between -2.5 and $-1.3 \%$ in the Tazcatemanto, between 5.8 and 7.0\% in the Chalasmanto, and between 3.5 and $6.8 \%$ in the Cinco de Mayo manto. The $\delta^{34} \mathrm{~S}$ data for the La Libertad vein range between -3.7 and $-0.2 \%$, and those for the La Escondida stockwork range between -1.6 and $0.2 \%$. These compositions correspond essentially to chalcopyrite; only in the La Escondida- El Muerto stockwork the sole analyzed mineral was pyrite (see Table 2).

\subsection{Carbon and oxygen}

Carbon and oxygen isotopic compositions were determined for 3 limestone samples that host the IOCG mineralization at Guaynopa, and 31 calcite samples of the Tres Amigos, Cinco de Mayo, and Chalas mantos at the same deposit. Such analyses were performed by using the method by McCrea (1950), in which $\mathrm{CO}_{2}$ is released by means of the reaction of calcite with pureH3PO4 at $25{ }^{\circ} \mathrm{C}$ during $50 \mathrm{~h}$. Thematerial involved, the samples and the analysis were handled and prepared following the procedure described by Révész et al. (2001) and Révész and Landwehr (2002), using a Gas Bench II coupled with a Thermo Finnigan MAT 253 mass spectrometer available at the Instituto de Geología of the Universidad Nacional Autónoma de México. $813 \mathrm{C}$ values are reported as permil deviations fromthe VPDB standard normalized to the consensus values of $-46.6 \%$ for LSVEC $\left(\mathrm{LiCO}_{3}\right)$ and $+1.95 \%$ para for NBS19 (Coplen et al., 2006). $\delta^{18} \mathrm{O}$ values are reported as 
permil deviations from the VPDB and VSMOW standards, normalized as indicated by Coplen (1988). All the analyses were performed by using the LSVEC, NBS-19 and NBS18 reference material, and every 7 samples a $\mathrm{CaCO}_{3}$ (by Sigma) internal reference was placed in the sequence of samples in order to verify repetitivity and reproducibility, which needs to be b0.2\%o for both oxygen and carbon. Our working standard is $\mathrm{CO}_{2}$ at a $99.998 \%$ purity, which is calibrated at a daily basis with $\mathrm{CO}_{2}$ (by Oztech) with a certified isotopic composition of $\delta^{18} \mathrm{O}_{\mathrm{VPDB}}=-9.78 \%$ and $\delta^{13} \mathrm{C}_{\mathrm{VPDB}}=-10.99 \%$. An additional calcite control sample is placed every 7 samples, with a known isotopic composition of $\delta^{18} \mathrm{OVPDB}_{\mathrm{VPB}}=-21.4$ $\pm 0.06 \%$ and $\delta 13 \mathrm{CVPDB}=-8.08 \pm 0.05 \%$.

The results of the $\mathrm{C}$ and $\mathrm{O}$ isotopic studies of host rocks and mantos in Guaynopa are shown in Table 3 and Fig. 6. The host limestones correspond to the Middle Albian Lampazos Formation and span $\delta^{13} \mathrm{C}_{\mathrm{VPDB}}$ between 3.20 and 3.53\%, and $\delta^{18} \mathrm{O}_{\mathrm{VPDB}}$ between -14.01 and $-13.27 \%$ ( $\left(\delta^{18} \mathrm{O}_{\mathrm{VSMOW}}=16.62\right.$ and $17.23 \%$ ). Hydrothermal calcite from mineralized mantos spans the following compositions:

- $\delta^{13} \mathrm{C}_{\mathrm{VPDB}}$ between-5.22 and 3.45\%, and $\delta^{18} \mathrm{O}_{\mathrm{VPDB}}$ between-20.66 and $-13.47 \%$ $\left(\delta^{18} \mathrm{O}_{\mathrm{VSMOW}}=9.61\right.$ and $17.03 \%$ ) in the Tres Amigos manto.

- $\delta^{13} \mathrm{C}_{\mathrm{VPDB}}$ between -3.01 and $-2.39 \%$, and $\delta^{18} \mathrm{O}_{\mathrm{VPDB}}$ between -17.19 and $-16.03 \%$ $\left(\delta^{18} \mathrm{O}_{\text {vSMOw }}=13.19\right.$ and $17.23 \%$ ) in the Cinco deMayo manto.

- $\delta^{13} \mathrm{CV}_{\mathrm{PDB}}$ between-4.37 and $-1.26 \%$, and $\delta^{18} \mathrm{O}_{\mathrm{VPDB}}$ between-18.44 and $-15.73 \%$ $\left(\delta^{18} \mathrm{O}_{\text {VSMOW }}=11.90\right.$ and $\left.15.20 \%\right)$ in the Chalas manto.

$\delta^{18} \mathrm{O}_{\text {vSMOw }}$ values of water in equilibrium with calcite were calculated using the fractionation equation by Horita (2014), $\delta^{18} \mathrm{O}_{\mathrm{VS}}$ ow values of $\mathrm{CO}_{2}$ in equilibrium with calcite were calculated using the fractionation equation by Ohmoto and Rye (1979), and the $\delta^{13} \mathrm{C}_{\mathrm{VPDB}}$ values of $\mathrm{CO}_{2}$ in equilibrium with calcite were calculated using the fractionation equations by Bottinga (1969) and Ohmoto and Rye (1979). For suchcalculations, we used the temperatures of homogenization of fluid inclusions from the Tres Amigos and Chalas mantos (no such data are available for the Cinco deMayo manto). In order to ensure the representativity and likeliness of the calculated isotopic data, the temperatures chosen were the highest and lowest average temperatures of homogenization fromthe various analyzed samples in each mineralized manto. 


\section{5. ${ }^{40} \mathrm{Ar} /{ }^{39}$ Ar dating}

The ${ }^{40} \mathrm{Ar} /{ }^{39} \mathrm{Ar}$ analyses were performed at the Geochronology Laboratory of the Departmento de Geología, Centro de Investigación Científica y Educación Superior de Ensenada (CICESE, Mexico). The argon isotope experiments were conducted on a few flakes of fuchsite and biotite (from the potassic alteration assemblages around the Guaynopa IOCG mantos) separated from sample GUAYN-1. The mineral grainswere heatedwith a Coherent Ar-ion Innova 370 laser. The extraction system is on line with a VG5400 mass spectrometer. The sample and irradiation monitors, were irradiated in the Uenriched research reactor of University of McMaster in Hamilton, Canada, at position 5C. To block thermal neutrons, the capsule was covered with a cadmium liner during irradiation. To determine the neutron flux variations, aliquots of the irradiation monitor FCT-2 sanidine $(27.84 \pm 0.04 \mathrm{Ma})$ were irradiated alongside sample GUAYN-1. Upon irradiation the monitors were fused in one step while the fuchsite sample GUAYN-1 was step-heated. The argon isotopes were corrected for blank, mass discrimination, radioactive decay of 37Ar and 39Ar and atmospheric contamination. For the Ca neutron interference reactions, the factors given by Masliwec (1984) were used. The decay constants recommended by Steiger and Jäger (1977) were applied in the data processing. The equations reported by York et al. (2004)were used in all the straight line fitting routines of the argon data reduction. The relevant 40Ar/39Ar data are presented in Table 3, which includes the results of the individual steps, and the integrated, plateau and isochron ages. The analytical precision is reported as one standard deviation $(1 \sigma)$. The error in the integrated, plateau and isochron ages includes the scatter in the irradiation monitors.

The 40Ar-39Ar results are listed in Table 3 and presented in Fig. 7. With the exception of the first fraction, a well-defined straight line, with mean standard weight deviations (MSWD) of 0.55 for $n=6$, indicates isochron ages of $96.66 \pm 0.71 \mathrm{Ma}$ for fuchsite and $97.64 \pm 0.29$ for biotite, which are statistically indistinguishable from the plateau ages. We then take the $98.12 \pm 0.37$ and $95.42 \pm 0.71 \mathrm{Ma}$ (Cenomanian) from the plateau ages of biotite and fuchsite, respectively, as our best estimates for the age of sample GUAYN-1.

\section{U-Pb dating}


Three samples were selected for $\mathrm{U}-\mathrm{Pb}$ dating in zircon separates from Guaynopita: two samples from instrusive bodies (sample GRANO-7, diorite, and sample CAMP, granodiorite), and a sample from a potassium feldspar from the potassic alteration assemblage around quartz veins and veinlets (sample L-9). The U-Pb zircon analyses were performed at the Isotopic Studies Laboratory (LEI) at the Centro de Geociencias from the Universidad Nacional Autónoma de México. An excimer (193 nm) laser ablation system by Resonetics was attached to a quadrupole Thermo-X series ICP-MS spectrometer to carry out the analyses. The system has been recently described by Solari et al. (2010) and all data have been reduced by in-house software "UPb.age" (Solari and Tanner, 2011) and plotted with the computational software "Isoplot 3.0" (Ludwig, 2003).

The analyzed samples yielded concordant ages at 92.4 Ma for the diorite intrusive, 89.1 Ma for the granodiorite intrusive (both hosting the porphyry copper deposit), and $84.4 \mathrm{Ma}$ for the potassic alteration assemblage in the porphyry copper deposit. These analyses are displayed in Table 4 and Fig. 8. (See Table 5.).

\section{Discussion}

\subsection{The formation of the guaynopa and guaynopita deposits}

According to our results, the Guaynopa IOCG deposits and the Guaynopita porphyry copper deposit in Chihuahua, plus the associated intrusives, formed at leastwithin a time span of $\sim 10 \mathrm{~m}$.y., as featured by the following ages: $98.15 \mathrm{Ma}$ for biotite and $95.42 \mathrm{Ma}$ for fuchsite in the potassic alteration assemblages of the IOCG deposit, 92.4 Ma for a diorite intrusive, 89.1Ma for a granodiorite intrusive (both hosting the porphyry copper deposit), and 84.4 Ma for potassic alteration in the porphyry copper deposit (hydrothermal zircon). Such time span is in agreementwith those determined in other Mexican IOCG 'clan' deposits (e. g., Peña Colorada in Colima; Camprubí et al., 2011; Camprubí and GonzálezPartida, 2016-in this issue), as the ore-forming phenomena are relatively long lasting within favorable regions with a complex structural configuration. Widely know features for generic MHIO are (1) the entrainment at different scales of observation (regional and local) 
of both alkaline and calc-alkaline magmas within a relatively short period of time, which are associated with the formation of either generic MHIO or porphyry-type $(\mathrm{Cu}, \mathrm{Mo}$, $\mathrm{Au}, \mathrm{W}$ ) deposits, and (2) the relatively wide variety of tectonomagmatic environments in which generic MHIO deposits formed (e.g., Williams et al., 2005). It has been long suspected that porphyry-type and some types of MHIO deposits may have a common ancestry in Andean-type settings. In fact, recent research in mineralized magmatichydrothermal paleosystems in Northern Chile (Tornos et al., 2010) allowed to invoke such common origin at a local scale, and suggests a "broadly contemporaneous" formation of similar deposits at a regional scale. In that case, the Tropezón $\mathrm{Cu}-\mathrm{Mo}-(\mathrm{Au})$ deposit in Chile bears characteristics of both IOCG and porphyry-hosted deposit models, which led Tornos et al. (2010) to suggest that this deposit represents a 'missing link' between both the consideredmodels. However, the Guaynopa-Guaynopita cluster contains separate ore deposits that can be formally ascribed to both the above models with no 'missing link' ever found so far, despite being so close in time and space. The broadly contemporaneous formation of both types of deposits also includes the emplacement of at least some of the local ('parental'?) intrusive bodies; one of them, which hosts the porphyry copper deposits, is nearly (and notably) contemporaneous to the IOCG deposit. Such features also for a continuum of some sort between IOCG and porphyry-copper deposits that formed as a result of an enabling evolution of parental magmas, and the occurrence of a Tropezón-like 'missing link' between them seems not an unreasonable possibility. Flores (1951) already noticed that several MHIO deposits were consistently associated with (or even rooted on) porphyry copper deposits or non-iron oxide skarns in association with the MesozoicCenozoic magmatism due to the Pacific arc in Mexico. At least two Cenozoic likely examples for the above are known in Mexico. One of them is represented by some small deposits (e. g., La Piedra Imán, El Sol y La Luna) in the Concepción del Oro corridor in eastern Zacatecas, which includes the giant non-iron oxide skarn deposits of Peñasquito (477 Mt in hypogene sulfides and $87 \mathrm{Mt}$ in supergene oxides, containing $575 \mathrm{Moz} \mathrm{Ag}$, 10Moz $\mathrm{Au}$, 1.67Mt $\mathrm{Pb}$ and 3.62 Mt $\mathrm{Zn}$; data from 2006, in Turner, 2009). The second example that can be invoked is the suite of deposits associated with the San Carlos caldera in Chihuahua (dated at $31 \mathrm{Ma}$; Immitt and Kyle, 1981), where magnetite-rich skarn 
deposits formed in association with $\mathrm{Pb}-\mathrm{Zn}$ skarns and epithermal veins (Clark and Fitch, 2009).

The case of theGuaynopa-Guaynopita group of deposits, for regional exploration purposes, may also benefit from its comparison with the geological characteristics of the Cenozoic Eastern Alkaline Province (EMAP) of Mexico. The most relevant of these (Camprubí, 2009, 2013), for the matter, are that (1) the EMAP is constituted by a series of magmatic massifs that are discontinuously distributed in a relatively narrowstrip of land that crosses the entire easternMexico fromCoahuila and Chihuahua in the north to Chiapas in the south, (2) it is the metallogenic province inMexicowith the highest 'typological diversity', as it contains a myriad of types and styles of magmatic-hydrothermal ore deposits, including both generic MHIO deposits, carbonatitic complexes, and ultra-alkaline massifs, and (3) the 'parental' magmatic rocks for these deposits have either alkaline or calc-alkaline affinities, as well as both intraplate and subduction affinities, even within the same individual magmatic massif (Camprubí, 2009, 2013). Such magmatism and magmatically driven metallogenic activity "unzips" southwards and correlates with the distribution in time and space of the eastward and southwardmigration of the Cenozoic arc magmatism. Therefore, the EMAP is likely to constitute a large-scale continental extensional back-arc province for the Cenozoic Sierra Madre Occidental SLIP. Whether or not the tectonomagmatic setting of northwestern Mexico during the Upper Cretaceous parallels in any way the one existing in the EMAP (though at a smaller scale), the sole occurrence of theGuaynopa-Guaynopita cluster should be enough to encourage research efforts towards evaluating such possibility. Ifwe assumed that to be the case, it might be predicted the occurrence of more deposits similar to those in the Guaynopa-Guaynopita cluster along the trace of the Basin and Range province in northwestern Mexico during the Upper Cretaceous.

\subsection{Fluid inclusion and stable isotope data}

Some of the temperatures of ice melting listed above are lower than the eutectic temperature of the $\mathrm{H}_{2} \mathrm{O}-\mathrm{NaCl}$ system, which is an expected effect for $\mathrm{CO}_{2}$-rich fluid inclusions (Hedenquist and Henley, 1985; Fáll et al., 2011), as it is actually the case for 
some fluid inclusion assemblages in the Guaynopa deposit (Fig. 3-C). However, such melting temperatures can also be accounted by (1) $\mathrm{H}_{2} \mathrm{O}-\mathrm{NaCl}-\mathrm{FeCl}_{2}$ or $\mathrm{H}_{2} \mathrm{O}-\mathrm{FeCl}_{2}$ fluids (Lecumberri-Sanchez et al., 2015; Steele-MacInnis et al., 2015), (2) $\mathrm{H}_{2} \mathrm{O}-\mathrm{NaCl}-\mathrm{CaCl}_{2}$ fluids (Hunt et al., 2011; Steele-MacInnis et al., 2011), or (3) be due to largely unpredictable metastability problems in the $\mathrm{H} 2 \mathrm{O}-\mathrm{NaCl}-\mathrm{CaCl}_{2}$ or $\mathrm{H}_{2} \mathrm{O}-\mathrm{NaCl}-\mathrm{MgCl}_{2}$ systems (Bakker and Baumgartner, 2012), as all these cases are plausible for the Guaynopa deposit. Until the current studies in the Guaynopa and Guaynopita deposits are properly completed and their salinity is recalculated as suggested by Fáll et al. (2011); SteeleMacInnis et al. (2011, 2015) or Lecumberri-Sanchez et al. (2015), the salinities displayed above must be cautionarily considered as apparent salinities when referred to $\mathrm{NaCl}$ alone.

In the Guaynopa IOCG deposits, the highest temperatures of homogenization (Th) were obtained in stockwork and vein fluid inclusion samples, which span very similar ranges of variation $\left(310^{\circ}\right.$ to $\left.410{ }^{\circ} \mathrm{C}\right)$. Also, apparent salinities from vein inclusion fluids (between 11.1 and 21.0 wt.\% $\mathrm{NaCl}$ equiv.) encompass those from stockwork samples. Contrastingly, fluid inclusions from manto samples show neatly lower Th (between $152^{\circ}$ and $310^{\circ} \mathrm{C}$ ) and higher apparent salinities (between 10.7 and $24.2 \mathrm{wt} . \% \mathrm{NaCl}$ equiv.) than those fromvein and stockwork assemblages, and both Th and apparent salinity are higher in the Chalas manto than in the Tres Amigos manto. The highest temperatures of homogenization (up to $448^{\circ} \mathrm{C}$ ) were obtained in stockwork samples from the Guaynopita porphyry copper deposit, although the ranges for them are very similar to those obtained for the Guaynopa IOCG deposit. Then, mineralizing fluids for both sets of deposits are intermediate- to hightemperature and relatively high-salinity brines. The ranges of Th and apparent salinities from IOCG associations at Guaynopa are in agreement with those commonly found in fluid inclusions from deposits of different types within the IOCG 'clan' (e. g., Borrok et al., 1998; Smith and Henderson, 2000; Bastrakov et al., 2007; Davidson et al., 2007), within the medium-salinity range (10 to $30 \mathrm{wt} . \% \mathrm{NaCl}$ equiv.). At the present state of research, only a fewfluid inclusionswith daughter minerals (Table 1 and Fig. 3-E) have been found in samples from the Guaynopita porphyry copper deposit, which is a striking feature for this type of deposits. However, this study is based only on limited surface sampling, as there are no old mines or drill cores available from these deposits; therefore, this study constitutes only a first approximation to its full-length metallogenic characterization. 
The trends of microthermometric data fromthe Guaynopa IOCG and the Guaynopita porphyry copper deposits are, even at the preliminary stage of research in these deposits, strikingly different. The observed petrographic evidence for boiling (i.e. coexistence in the same fluid inclusion associations of vapor-rich and liquid-rich inclusions) in the La Libertad vein could suggest that high-salinity fluids might constitute "false brines" due to boiling-off of vapor. Although the consistency of data from that vein and the similar microthermometric behavior of fluid inclusions from IOCG mineralizations may rule out "false brines" as responsible for relatively high salinities in mantos, the geometry of the two subsets of microthermometric data from the La Libertad vein may either be due to (1) boiling fromhigh-temperature andmoderately saline brines, or (2) different brine pulseswith contrasting temperature and salinity. Most of the fluid inclusion assemblages (FIAs) analyzed in IOCG ores display data trends that are either suggestive of isothermal mixing (similar Th but varying salinity, as in manto and vein samples) or of conductive cooling (similar salinity but varying $\mathrm{Th}$, as in manto and stockwork samples). Contrastingly, fluid inclusions from the Guaynopita porphyry copper deposit display a positive correlation between Th and apparent salinity, thus standing for a convincing dilution trend between relatively high salinity and temperature fluids, and water likely derived from meteoric sources. Such dilution trend is found both in every FIA and as a general trend for the whole set of data in the Guaynopita porphyry copper deposit.

As a general feature, the $\mathrm{C}$ and $\mathrm{O}$ isotopic compositions of host limestones of the Lampazos Formation are compatible with those of marine Albian-Cenomanian limestones (Huber et al., 1999; Norris et al., 2001; Zürcher et al., 2001). Further, such compositions were shifted towards lower $\delta^{18} \mathrm{O}$ values (Fig. 6) as the rocks of the Lampazos Formation underwent rock-dominated interaction withmineralizing fluids during hydrothermal stages of the Guaynopa deposit. According to Zheng and Hoefs (1993), magmatic water may have

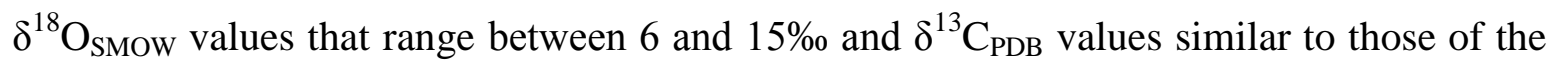
undepleted mantle (between -9 and $-4 \%$ ). Therefore, $\mathrm{C}$ and $\mathrm{O}$ isotopic compositions of hydrothermal calcite from mineralized mantos at Guaynopa, and of $\mathrm{CO}_{2}$ and water in isotopic equilibrium with calcite show, in general, mixed sources between compositions that correspond tomagmatic fluids and marine limestones. However, the analytical data have a strong affinity with magmatic isotopic compositions, which is corroborated by the 
calculated $\delta^{18} \mathrm{O}$ and $\delta^{13} \mathrm{C}$ values of $\mathrm{CO}_{2}$ in isotopic equilibrium with calcite. This interpretation is valid at a broad variety of temperatures andwater/rock interaction models (Fig. 6). Then, it follows thatmineralizing fluids in the Guaynopa deposit would have been essentially magmatic brines (up to $\mathrm{N} 24$ wt.\% $\mathrm{NaCl}$ equiv. or more) that underwent significant interaction with the local host rocks. Also, $\delta^{18} \mathrm{O}_{\text {SMOW }}$ values of water in equilibrium with calcite (between -5.22 and 2.21\%o) suggest that upwelling fluids interacted with meteoric water, similarly to the case described for Mexican epithermal deposits by Albinson et al. (2001) and Camprubí et al. (2001). Such interactionwould account for the isothermal mixing and dilution features deduced from the behavior of fluid inclusion microthermometric data (Fig. 4).

Most of the sulfides display a bimodal distribution of $\delta^{34} \mathrm{~S}$ values, roughly between-4 and 1\%, and between 2 and 7\%, although chalcopyrite samples fromsomemanto associations span values below-9\%o. The former range of data is compatible with magmatic sources for sulfur, either derived from cooling magmas or, less likely, leached from igneous rocks by relatively oxidized fluids. The likeliness of the coolingmagmahypothesis is implied by the relatively high apparent salinities obtained in fluid inclusions frommanto assemblages, which can be attained by magmatic brines (with some degree of entrainment of more oxidized and dilute surficial waters) in settings where no modified seawater, sedimentary or bittern brines can be related to the generation of mineralizing brines. The obtained range of $\delta^{34} \mathrm{~S}$ values includes most data frommanto samples and all of the stockwork samples. Vein samples peak between -3 and $-2 \%$, thus probably reflecting magmatic sources for sulfur under increasingly oxidizing conditions departing from the $\sim 0 \%$-centered values in stockwork assemblages. The highest $\delta^{34} \mathrm{~S}$ values (up to $6.8 \%$ ), obtained in the Chalas and Cinco de Mayo mantos, are seemingly not high enough as to allow invoke the incursion of modified seawater as in the Mantoverde deposit in Chile (Benavides et al., 2007) and most deposits in the Coastal Andes Cordillera (Williams et al., 2005). Instead, these values would be associated with crustal sedimentary rocks as in other IOCG 'clan' deposits (Bastrakov et al., 2007; Chen and Zhou, 2012). In this sense, it is worth noting that the location of the Guaynopa deposits, over $500 \mathrm{~km}$ inland from the paleo-Pacific margin, and that formed during the continentalization process of magmatism and metallogeny in Mexico, renders the role of modified seawater unlikelier than in intra- 
arc settings like those in the Coastal Andes Cordillera. The large negative $\delta^{34} S$ values in the Tres Amigos manto, in which chalcopyrite is associated with martitization and the lowest temperatures of homogenization were obtained, can be explained by the oxidation of mineralizing fluids over time, as in other IOCG deposits (Bastrakov et al., 2007; Davidson et al., 2007). Such late oxidized fluids can be interpreted as surficial waters that became more efficiently entrained by upwelling fluids as the paleohydrothermal system waned. Such feature is not uncommonly invoked for other relatively shallow deposits of the IOCG 'clan' (Borrok et al., 1998; Reynolds, 2000; Bastrakov et al., 2007). This possibility is compatible by the isothermal mixing trend suggested by the distribution of microthermometric data in the Tres Amigos manto (Table 1), which span a difference of apparent salinities of over 4 wt. $\% \mathrm{NaCl}$ equiv. in fluid inclusions with an extremely narrow variation range in temperatures of homogenization. The features concerning the likely sources for sulfur discussed above are similar to those described in the IOCG deposits of the Mantoverde and Olympic Dam districts (Bastrakov et al., 2007; Benavides et al., 2007; Davidson et al., 2007; Rieger et al., 2010).

\subsection{The troublesome occurrence of fuchsite at Guaynopa}

The prominent occurrence of epigenetic fuchsite (chromian muscovite) as part of the potassic alteration assemblage, which contains the iron oxide-copper-gold associations in the main mantos, is an interesting feature in the Guaynopa deposit. This deserves further attention although such occurrence cannot be easily explained. Fuchsite (or, for that matter, chromian phengite or "mariposite") is seemingly an extremely uncommon epigenetic mineral variety in generic magmatic-hydrothermal iron oxide deposits, unless it takes after preexisting minerals in several types of deposits. Typical cases would be orogenic deposits (i.e., "listvenites") or other types of deposits in which chromium was remobilized from underlying ultramafic-mafic rock complexes (e.g., Nesbitt et al., 1986; Partington and Williams, 2000; Jébrak and Doucet, 2002; Baksheev and Kudryavtseva, 2004; Haeberlin et al., 2004; Doroshkevich et al., 2007; Dubé and Gosselin, 2007; Espi et al., 2007; Holma and Keinänen, 2007; Belkabir et al., 2008; Peltonen et al., 2008; González-Jiménez et al., 2014), or associated with banded iron formations (Hall and Goode, 1978; Jenkins and 
Alibert, 1991; Kwitko et al., 2002; Elkady, 2003; Bhattacharya et al., 2007). Chromian muscovite or phengite have seldom been described in skarn deposits and other rock assemblages due to thermal metamorphism (Rumyantseva, 1983; Kazachenko et al., 1993; Uher et al., 2008) as well. They have also been found in some carbonatite deposits, in association with calcite, dolomite, apatite, albite, sodic amphiboles and chlorite (Nelson et al., 1988), although no clear paragenetic correspondence between these minerals and fuchsite or mariposite was established by the authors above. In other carbonatite deposits, chromian phengite is found in late assemblages due to regional metamorphism within carbonatitic assemblages or in xenoliths in association with magnetite (Doroshkevich et al., 2007; Ripp et al., 2007). Only recently fuchsite has been found in another IOCG deposit: Tatatila-Las Minas in Veracruz, also in Mexico, which is Miocene in age and related to the Eastern Mexico Alkaline Province (Camprubí, 2013). Notice that Groves and Vielreicher (2001), Gandhi (2003) and Pirajno (2009), among others, concur in placing carbonatite and similar deposits (the Phalaborwa and Bayan Obo types) as end-members in the IOCG 'clan'.

Does the above mean that there are ultramafic-mafic complexes so far unheard of within the local Early Cretaceous sequences in the study area? Otherwise, may it be that the Guaynopa deposit has unusually high chromium contents associated with unknown magmaticmetallogenic processes? (Or none of these?) Provided that some types of deposits in ultramafic-mafic complexes and in the IOCG 'clan' form in extensional environments (though they occur in quite different settings), could it be possible that there is some sort genetic link between chromium-producing magmas and those associated with MHIO deposits? The association of gabbroic to intermediate magmas with the latter may be an important clue for further research. Hitherto, none of these questions can be answered, especially in the preliminary state of research in the Guaynopa deposit and the broad spectrum of types of deposits encompassed into the IOCG 'clan'. However, for comparison, it is interesting to be aware of the geological characteristics of the Cenozoic Eastern Magmatic Alkaline Province (EMAP) of Mexico, discussed earlier in this paper.

\section{Conclusions}


- There may have an unfathomed potential formagmatic-hydrothermal iron oxide (MHIO) deposits in Mexico during the Mesozoic, as suggested by new data from the Guaynopa deposit in Chihuahua. Most Mesozoic MHIO deposits in Mexico occur in subductionrelated continental margins near the continental edge, and these have been interpreted to form in intra-arc environments, much alike those in the Coastal Andes Cordillera. However, other deposits (i.e., Guaynopa, Cerro del Oro) are found up to $\sim 500 \mathrm{~km}$ inland from the continental paleo-edge, and thus other settings must be invoked (associated with back-arc magmatism?).

- The Guaynopa and Guaynopita deposits in west-central Chihuahua were formed in association with granitic intrusions of the Lower Volcanic Complex (Sierra Madre Occidental SLIP) that intruded a Lower Cretaceous sequence of carbonate and fine detritic rocks and developed contact skarns. These deposits are barely separated by 5 $\mathrm{km}$ and are likely to represent a single metallogenic event previously unrecorded in this area, though the study presented in this paper is largely preliminary and still under way for both metallogenetic and petrogenetic matters. The Guaynopa deposits are constituted by iron oxide- $\mathrm{Cu}-\mathrm{Au}$ associations in mantos, veins and stockworks, with associated fuchsite, biotite or potassium feldspar (potassic assemblages), tremoliteactinolite (calcic-sodic assemblages) and, locally, hypogene propylitic and argillic alteration assemblages.

- The temperatures of homogenization and apparent salinities of inclusion fluids, and $\delta^{34} \mathrm{~S}$ values of sulfides in the Guaynopa deposit are quite similar to those found in other deposits of the IOCG 'clan' elsewhere, although only medium-range apparent salinities were obtained. $\delta^{18} \mathrm{O}$ and $\delta^{13} \mathrm{C}$ values of hydrothermal calcite, and those calculated for $\mathrm{CO}_{2}$ and water suggest that mineralizing fluids came from magmatic sources and underwent significant interaction with host rocks and meteoric fluids., Such feature is compatible with dilution and mixing patterns of mineralizing brines and the evolution of mineral assemblages, from relatively reduced magnetite-chalcopyrite to more oxidized hematite-dominated assemblages. Data trends in individual fluid inclusion assemblages from either manto, stockwork and vein mineral assemblages can be interpreted as indicative of isothermal mixing, conductive cooling, or boiling. Contrastingly, fluid inclusions from the Guaynopita porphyry copper deposit display 
quite clear trends for progressive dilution of possibly magmatic fluids, at the scale of fluid inclusion assemblages or at a broader one.

- 40Ar/39Ar dating in biotite and chromian muscovite (fuchsite) from mantos at the Guaynopa IOCG deposits yielded respective plateau ages at 98.12 \pm 0.37 and $95.42 \pm 0.71 \mathrm{Ma}$ (Cenomanian).U-Pb dating in zircons from diorite and granodiorite intrusives related to the Guaynopita porphyry copper deposit, and from its potassic alteration assemblage yielded ages at 92.4 $\pm 0.5 \mathrm{Ma}, 89.1 \pm 0.7 \mathrm{Ma}$ (Turonian to Coniacian), and 84.4 \pm 1.0 Ma (Santonian), respectively. Therefore, there is a minimum $\sim 14 \mathrm{~m}$.yr. period of metallogenic andmagmatic activity in the area. This attests for a long-lasting magmatic-hydrothermal system, which could suggest a common tectonomagmatic ancestry for both deposits. In addition, the obtained ages render new possibilities for exploration in northwestern Mexico for both types of deposits in Cretaceous rock assemblages.

- Coarse-grained fuchsite (chromian muscovite) within the Guaynopa deposit as part of the potassic alteration assemblage is an uncanny and previously undocumented mineral occurrence for IOCG deposits, and might be indicative of undiscovered chromium resources in this region.

\section{Acknowledgments}

Financial support for this paper was obtained through the CONACYT research program (grant IN155662 to A. Camprubí). Additional funding was received from internal annual research budgets of the Instituto de Geología, the Instituto de Geofísica and the Centro de Geociencias (UNAM). M.A. García-García is thanked for his assistance in the 40Ar/39Ar experiments, for which A.S. Rosas-Montoya was in charge of the mineral separation and preparation of the analyzed samples at the CICESE, and Carlos Ortega-Obregón was the technician in charge of the U-Pb determinations at the Centro deGeociencias (UNAM). Mike Porter lent a hand in our "fuchsite trouble" by kindly scanning his huge ore deposit database. Matthew Steele-MacInnis and an anonymous reviewer are wholeheartedly acknowledged for their insightful reviews. 


\section{References}

Albinson, T., Norman, D.I., Cole, D., Chomiak, B.A., 2001. Controls on formation of low sulfidation epithermal deposits in Mexico: constraints from fluid inclusion and stable isotope data. Soc. Econ. Geol. spec. Publ. 8, 1-32.

Andersen, T., 2002. Correction of common lead in U-Pb analyses that do not report $204 \mathrm{~Pb}$. Chem. Geol. 192, 59-79.

Bakker, R.J., Baumgartner, M., 2012. Unexpected phase assemblages in inclusions with ternary $\mathrm{H}_{2} \mathrm{O}$-salt fluids at low temperatures. Cent. Eur. J. Geosci. 4, 225-237.

Baksheev, I.A., Kudryavtseva, O.E., 2004. Nickeloan tourmaline from the Berezovskoe gold deposit, Middle Urals, Russia. Can. Mineral. 42, 1065-1078.

Bastrakov, E.N., Skirrow, R.G., Davidson, G.J., 2007. Fluid evolution and origins of iron oxide $\mathrm{Cu}-\mathrm{Au}$ prospects in the Olympic Dam District, Gawler Craton, South Australia. Econ. Geol. 102, 1415-1440.

Belkabir, A., Jébrak, M.,Maacha, L., Azizi Samir, M.R., Madi, A., 2008. Gold mineralization in the Proterozoic Bleida ophiolite, Anti-Atlas, Morocco. In: Ennih, N., Liégeois, J.-P. (Eds.), The Boundaries of theWest African Craton. Geological Society Special Publication 297, pp. 249-264.

Benavides, J., Kyser, T.K., Clark, A.H., Oates, C.J., Zamora, R., Tarnovischi, R., Castillo, B., 2007. The Mantoverde iron oxide-copper-gold district, III Región, Chile: the role of regionally derived, nonmagmatic fluids in chalcopyrite mineralization. Econ. Geol. $102,415-440$.

Bhattacharya, H.N., Chakraborty, I., Ghosh, K.K., 2007. Geochemistry of some banded ironformations of the Archean supracrustals, Jharkhand-Orissa region, India. J. Earth Syst. Sci. 116, 245-259.

Bodnar, R.J., 1993. Revised equation and table for determining the freezing point depression of $\mathrm{H}_{2} \mathrm{O}-\mathrm{NaCl}$ solutions. Geochim. Cosmochim. Acta 57, 683-684.

Bodnar, R.J., Sterner, S.M., Hall, D.L., 1989. SALTY: A FORTRAN program to calculate compositions of fluid inclusions in the system $\mathrm{NaCl}-\mathrm{KCl}-\mathrm{H}_{2} \mathrm{O}$. Comput. Geosci. 15, $19-41$. 
Borrok, D.M., Kesler, S.E., Boer, R.H., Essene, E.J., 1998. The Vergenoeg magnetitefluorite deposit, South Africa: support for a hydrothermal model for massive iron oxide deposits. Econ. Geol. 93, 564-586.

Bottinga, Y., 1969. Calculated fractionation factors for carbon and hydrogen isotope exchange in the system calcite-carbon dioxide-graphite-methane-hydrogen-water vapor. Geochim. Cosmochim. Acta 33, 49-64.

Camprubí, A., 2009. Major metallogenic provinces and epochs of Mexico. SGA News 25, $1-20$.

Camprubí, A., 2013. Tectonic and Metallogenic History of Mexico. In: Colpron, M., Bissig, T., Rusk, B.G., Thompson, J.F.H. (Eds.), Tectonics, Metallogeny, and Discovery: the North American Cordillera and Similar Accretionary Settings. Society Of Economic Geologists, Special Publication 17, pp. 201-243.

Camprubí, A., González-Partida, E., 2016. Mesozoic magmatic-hydrothermal iron oxide deposits (IOCG 'clan') in Mexico: a review. Ore Geol. Rev. 81, 1084-1095 (in this issue).

Camprubí, A., Cardellach, E., Canals, À., Lucchini, R., 2001. The La Guitarra Ag-Au low sulfidation epithermal system, Temascaltepec district, Mexico: fluid inclusion and stable isotope data. Soc. Econ. Geol. spec. Publ. 8, 159-185.

Camprubí, A., Tolson, G., Centeno-García, E., Ortega, B., Bolaños, D., Portugal-Reyna, J.L., Aguilar-Hernández, J.A., Corona-Chávez, P., 2011. Mineralogy, ${ }^{40} \mathrm{Ar} /{ }^{39} \mathrm{Ar}$ Dating and Structural Analysis of the Peña Colorada Magnetite Deposits (Colima, Mexico). In: Barra, F., Reich, M., Campos, E., Tornos, F. (Eds.), 11th SGA Biennial Meeting Let's Talk Ore Deposits v. 2. Ediciones Universidad Católica del Norte, Antofagasta, Chile, pp. 446-448.

Chen,W.T., Zhou, M.-F., 2012. Paragenesis, stable isotopes, and molybdenite Re-Os isotope age of the Lala iron-copper deposit, Southwestern China. Econ. Geol. 107, $459-480$.

Clark, K.F., Fitch, D.C., 2009. Evolución de depósitos metálicos en tiempo y espacio en México. In: Clark, K.F., Salas-Pizá, G., Cubillas-Estrada, R. (Eds.), Geología Económica de México, second ed. Servicio Geológico Mexicano - Asociación de Ingenieros de Minas, Metalurgistas y Geólogos de México, pp. 62-133. 
Coplen, T.B., 1988. Normalization of oxygen and hydrogen isotope data. Chem. Geol. 72, 293-297.

Coplen, T.B., Brand, W.A., Gehre, M., Gröning, M., Meijer, H.A.J., Toman, B., Verkouteren, R.M., 2006. New guidelines for $\delta 13 \mathrm{C}$ measurements. Anal. Chem. 78, 2439-2441.

Davidson, G.J., Paterson, H., Meffre, S., Berry, R.F., 2007. Characteristics and origin of the Oak Dam East breccia-hosted, iron oxide $\mathrm{Cu}-\mathrm{U}-(\mathrm{Au})$ deposit: Olympic Dam region, Gawler Craton, South Australia. Econ. Geol. 102, 1471-1498.

Doroshkevich, A.G., Wall, F., Ripp, G.S., 2007. Calcite-bearing dolomite carbonatite dykes fromVeseloe, North Transbaikalia, Russia and possible Cr-richmantle xenoliths. Mineral. Petrol. 90, 19-49.

Dubé, B., Gosselin, P., 2007. Greenstone-hosted quartz-carbonate vein deposits. In: Goodfellow, W.D. (Ed.), Mineral Deposits of Canada: A Synthesis of Major DepositTypes. District Metallogeny, the Evolution of Geological Provinces, and Exploration Methods, Geological Association of Canada, Mineral Deposits Division, Special Publication 5, pp. 49-73.

Elkady, M.F., 2003. Structural Evolution in the Palaeoproterozoic Basement (Banded Iron Formation and Related Rocks) of SW Egypt. Unpublished PhD dissertation, RuprechtKarls-Universität Heidelberg, Heidelberg, Gemany, 139 pp.

Espi, J.O., Hayashi, K.-I., Komuro, K., Murakami, H., Kajiwara, Y., 2007. Geology, wallrock alteration and vein paragenesis of the Bilimoia gold deposit, Kainantu metallogenic region, Papua New Guinea. Resour. Geol. 57, 246-268.

Fáll, A., Tattitch, B., Bodnar, R.J., 2011. Combined microthermometric and Raman spectroscopic technique to determine the salinity of $\mathrm{H}_{2} \mathrm{O}-\mathrm{CO}_{2}-\mathrm{NaCl}$ fluid inclusions based on clathrate melting. Geochim. Cosmochim. Acta 75, 951-964.

Ferrari, L., Valencia-Moreno, M., Bryan, S., 2005. Magmatismo y tectónica en la Sierra Madre Occidental y su relación con la evolución de la margen occidental de Norteamérica. Bol. Soc. Geol. Mex. 57, 343-378.

Ferrari, L., Valencia-Moreno, M., Bryan, S., 2007. Magmatism and tectonics of the Sierra Madre Occidental and its relation with the evolution of the western margin of North America. In: Alaniz-Álvarez, S.A., Nieto-Samaniego, A.F. (Eds.), Geology of México: 
Celebrating the Centenary of the Geological Society OfMéxico. Geological Society Of America Special Paper 422, pp. 1-39.

Flores, T., 1951. Geología, génesis y condiciones estructurales de los yacimientos de fierro de México. Inst. Nac. Invest. Recur. Mineral. Bol. 29 (30 pp.).

Gandhi, S.S., 2003. An overview of the $\mathrm{Fe}$ oxide- $\mathrm{Cu}-\mathrm{Au}$ deposits and related deposit types. CIMMontréal 2003 Mining Industry Conference and Exhibition, Canadian Institute of Mining, Technical Paper, CD-ROM.

González-Jiménez, J.M., Barra, F.,Walker, R.J., Reich, M., Gervilla, F., 2014. Geodynamic implications of ophiolitic chromitites in the la Cabaña ultramafic bodies, Central Chile. Int. Geol. Rev. 56, 1466-1483.

González-Partida, E., Canet, C., Camprubí, A., González-Ruiz, L., 2011. Guaynopa y Guaynopita, dos tipologías de mineralización de edad Cretácico Superior en la Sierra Madre Occidental, México. Actas INAGEQ 17, 156.

Groves, D.I., Vielreicher, N.M., 2001. The Phalaborwa (Palabora) carbonatite-hosted magnetite-copper sulfide deposit, South Africa: an end member of the iron-oxidecopper-gold-rare earth element deposit group? Mineral. Deposita 36, 189-194.

Haeberlin, W., Moritz, R., Fontboté, L., 2004. Carboniferous orogenic gold deposits at Pataz, eastern Andean Cordillera, Peru: geological and structural framework, paragenesis, alteration, and ${ }^{40} \mathrm{Ar} /{ }^{39} \mathrm{Ar}$ geochronology. Econ. Geol. 99, 73-112.

Hall, W.D.M., Goode, A.D.T., 1978. The early Proterozoic Nabberu Basin and associated iron formations of Western Australia. Precambrian Res. 7, 129-184.

Hedenquist, J.W., Henley, R.W., 1985. The importance of $\mathrm{CO}_{2}$ on freezing point measurements of fluid inclusions: evidence from active geothermal systems and implications for epithermal ore deposition. Econ. Geol. 80, 1379-1406.

Holma, M.J., Keinänen, V.J., 2007. The Levijärvi-Loukinen gold occurrence: an example of orogenic gold mineralisation with atypicalmetal association. In: Ojala, V.J. (Ed.), Gold in the Central Lapland Greenstone Belt, Finland. Geological Survey of Finland, Special Paper 44, pp. 165-184.

Horita, J., 2014. Oxygen and carbon isotope fractionation in the system dolomite-water$\mathrm{CO}_{2}$ to elevated temperatures. Geochim. Cosmochim. Acta 129, 111-124. 
Huber, B.T., Leckie, R.M., Norris, R.D., Bralower, T.J., CoBabe, E., 1999. Foraminiferal assemblage and stable isotopic change across the Cenomanian Turonian boundary in the subtropical Atlantic. J. Foraminifer. Res. 29, 392-417. Hunt, J.A., Baker, T., Cleverley, J., Davidson, G.J., Fallick, A.E., Thorkelson, D.J., 2011. Fluid inclusion and stable isotope constraints on the origin of Wernecke Breccia and associated iron oxide-copper-gold mineralization, Yukon. Can. J. Earth Sci. 48, 1425-1445.

Immitt, J.P., Kyle, R.J., 1981. Relation of skarn and epithermal veins to caldera development, San Carlos, Northern Chihuahua. Geological Society of America, Cordilleran Section Meeting Abstracts with Program, 62.

Jébrak, M., Doucet, P., 2002. Geology and gold-molybdenum porphyry mineralisation of the Archean Taschereau-Launay plutons, Abitibi, Quebec. Precambrian Res. 115, $329-348$.

Jenkins, C.J., Alibert, C., 1991. Sedimentary and metamorphic rock clasts from the Cenozoic diamictons of sites 739-743, Prydz Bay, east Antactica. Proc. Ocean Drill. Program Sci. Results 119, 133-141.

Kazachenko, V.T., Butsik, L.A., Sapin, V.I., Kitaev, I.V., Barinov, N.N., Narnov, G.A., 1993. Vanadian-chromian tourmaline and vanadian muscovite in contactmetamorphosed carbonaceous rocks, Primorye, Russia. Can. Mineral. 31, 347-356.

Kwitko, R., Cabral, A.R., Lehmann, B., LaFlamme, J.H.G., Cabri, L.J., Criddle, A.J., Galbiatti, H.F., 2002. Hongshiite, PtCu, from itabirite-hosted $\mathrm{Au}-\mathrm{Pd}-\mathrm{Pt}$ mineralization (Jacutinga), Itabira district, Minas Gerais, Brazil. Can. Mineral. 40, 711-723.

Lecumberri-Sanchez, P., Steele-MacInnis, M., Bodnar, R.J., 2015. Synthetic fluid inclusions XXI. Experimental determination of the vapor-saturated liquidus of the system $\mathrm{H}_{2} \mathrm{O}-\mathrm{NaCl}-\mathrm{FeCl}_{2}$. Geochim. Cosmochim. Acta 148, 34-49.

Ludwig, K.R., 2003. ISOPLOT, a Geochronological Toolkit for Microsoft Excel, Version 3.00. Berkeley Geochronology Center Special Publication 4 (70 pp.).

Masliwec, A., 1984. Applicability of the 40Ar/39Ar Method to the Dating of Ore Bodies. Unpublished PhD Dissertation. University of Toronto, Toronto, Ontario, Canada.

McCrea, J.M., 1950. On the isotopic chemistry of carbonates and paleotemperature scale. J. Chem. Phys. 18, 849-857. 
Monreal, R., Longoria, J.F., 2000a. Lower cretaceuos rocks of Sierra Los Chinos, eastcentral, Sonora. Geofis. Int. 39, 309-322.

Monreal, R., Longoria, J.F., 2000b. Stratigraphy and structure ofthe Lower Cretaceous of Lampazos, Sonora, (nortwest Mexico) and its relationship to the Gulf Coast succession. Bull. Am. Assoc. Pet. Geol. 84, 1811-1831.

Nelson, D.R., Chivas, A.R., Chappell, B.W., McCulloch, 1988. Geochemical and isotopic systematics in carbonatites and implications for the evolution of ocean-island sources. Geochim. Cosmochim. Acta 52, 1-17.

Nesbitt, B.E., Murowchick, J.B., Muehlenbachs, K., 1986. Dual origins of lode gold deposits in the Canadian Cordillera. Geology 14, 506-509.

Norris, R.D., Kroon, D., Huber, B.T., Erbacher, J., 2001. Cretaceous Palaeogene ocean and climate change in the subtropical North Atlantic. Geol. Soc. Spec. Publ. 183, 1-22.

Ohmoto, H., Rye, R.O., 1979. Isotope of sulfur and carbon. In: Barnes, H.L. (Ed.), Geochemistry of Hydrothermal Deposits. John Wiley \& Sons, pp. 509-567.

Partington, G.A., Williams, P.J., 2000. Proterozoic Lode Gold and (Iron)-Copper-Gold Deposits: a Comparison of Australian and Global Examples. In: Hagemann, S.G., Brown, P.E. (Eds.), Gold in 2000. Reviews in Economic Geology 13, pp. 69-101.

Peltonen, P., Kontinen, A., Huhma, H., Kuronen, U., 2008. Outokumpu revisited: new mineral deposit model for the mantle peridotite-associated $\mathrm{Cu}-\mathrm{Co}-\mathrm{Zn}-\mathrm{Ni}-\mathrm{Ag}-\mathrm{Au}$ sulphide deposits. Ore Geol. Rev. 33, 559-617.

Pirajno, F., 2009. Hydrothermal Processes and Mineral Systems. Springer (1250 pp.).

Pubellier, M., 1987. Relations entre domaines cordillerain et mésogéen au nord du Mexique, étude géologique de la vallée de Sahuaripa, Sonora. Unpublished PhD dissertation, Université de Paris VI, Paris, France, (219 pp.).

Révész, K.M., Landwehr, J.M., 2002. $\delta^{13} \mathrm{C}$ and $\delta^{18} \mathrm{O}$ isotopic composition of $\mathrm{CaCO} 3$ measured by continuous flow isotope ratio mass spectrometry statistical evaluation and verification by application to Devils Hole Core DH-11 Calcite. Rapid Commun. Mass Spectrom. 16, 2102-2114.

Révész, K.M., Landwehr, J.M., Keybl, J., 2001. Measurement of $\delta^{13} \mathrm{C}$ and $\delta^{18} \mathrm{O}$ Isotopic Ratios of $\mathrm{CaCO}_{3}$ using a Thermoquest Finnigan Gas Bench II Delta PLus XL 
Continuous Flow Isotope Ratio Mass Spectrometer with Application to Devils Hole Core DH-11 Calcite. U.S. Geological Survey, Open-File Report 01-257.

Reynolds, L.J., 2000. Geology of the Olympic Dam Cu-U-Au-Ag-REE deposit. In:

Porter, T.M. (Ed.), Hydrothermal Iron Oxide Copper-Gold and Related Deposits: a Global Perspective. PGC Publishing, Adelaide, Australia, pp. 93-104.

Rieger, A.A., Marschik, R., Díaz, M., Hölzl, S., Chiaradia, M., Akker, B., Spangenberg, J.E., 2010. The hypogene iron oxide-copper-gold mineralization in the Mantoverde district, northern Chile. Econ. Geol. 105, 1271-1299.

Ripp, G.S., Doroshkevich, A.G., Badmatsyrenov, M.V., Karmanov, N.S., 2007. Mantle(?) xenoliths in the carbonatites of northern Transbaikalia. Geochem. Int. 45, 538-545.

Rumyantseva, Ye.V, 1983. Chromdravite - a new mineral from Karelia. Int. Geol. Rev. 25, 989-992.

Sláma, J., Košler, J., Condon, D.J., Crowley, J.L., Gerdes, A., Hanchar, J.M., Horstwood,M.S.A., Morris, G.A., Nasdala, L., Norberg, N., Schaltegger, U., Schoene, B., Tubrett, M.N., Whitehouse, M.J., 2008. Plešovice zircon: A new natural reference material for $\mathrm{U}-\mathrm{Pb}$ and $\mathrm{Hf}$ isotopic microanalysis. Chem. Geol. 249, 1-35.

Smith, M.P., Henderson, P., 2000. Preliminary fluid inclusion constraints on fluid evolution in the Bayan Obo Fe-REE-Nb deposit, inner Mongolia, China. Econ. Geol. 95, 13711388.

Solari, L.A., Tanner, M., 2011. UPb.age, a fast data reduction script for LA-ICP-MS U-Pb geochronology. Rev. Mex. Cienc. Geol. 28, 83-91.

Solari, L.A., Gómez-Tuena, A., Bernal, J.P., Pérez-Arvizu, O., Tanner, M., 2010. U-Pb zircon geochronology by an integrated LA-ICPMS microanalytical workstation: achievements in precision and accuracy. Geostand. Geoanal. Res. 34, 5-18.

Steele-MacInnis, M., Bodnar, R.J., Naden, J., 2011. Numerical model to determine the composition of $\mathrm{H}_{2} \mathrm{O}-\mathrm{NaCl}-\mathrm{CaCl}_{2}$ fluid inclusions based on microthermometric and microanalytical data. Geochim. Cosmochim. Acta 75, 21-40.

Steele-MacInnis, M., Lecumberri-Sanchez, P., Bodnar, R.J., 2015. Synthetic fluid inclusions XX. Critical PTx properties of $\mathrm{H}_{2} \mathrm{O}-\mathrm{FeCl}_{2}$ fluids. Geochim. Cosmochim. Acta $148,50-61$. 
Steiger, R.H., Jäger, E., 1977. Subcommission on geochronology: convention on the use of decay constants in geo and cosmochronology. Earth Planet. Sci. Lett. 36, 359-362.

Tornos, F., Velasco, F., Barra, F., Morata, D., 2010. The Tropezón Cu-Mo-(Au) deposit, Northern Chile: the missing link between IOCG and porphyry copper systems? Mineral. Deposita 45, 313-321.

Turner, Y., 2009. La geología y los depósitosminerales del proyecto Peñasquito, Zacatecas, México. In: Clark, K.F., Salas-Pizá, G., Cubillas-Estrada, R. (Eds.), Geología económica de México, 2a edición Servicio Geológico Mexicano - Asociación de Ingenieros de Minas, Metalurgistas y Geólogos de México, pp. 925-931.

Uher, P., Kováčik, M., Kubiš, M., Shtukenberg, A., Ozdín, D., 2008. Metamorphic vanadian- chromian silicate mineralization in carbon-rich amphibole schists from the Malé Karpaty Mountains, Western Carpathians, Slovakia. Am. Mineral. 93, 63-73.

Valencia-Moreno, M., Ochoa-Landín, L., Noguez-Alcántara, B., Ruiz, J., Pérez-Segura, E., 2006. Características de los depósitos de pórfido cuprífero en México y su situación en el contexto mundial. Bol. Soc. Geol. Mex. 58, 1-26.

Valencia-Moreno, M., Ochoa-Landín, L., Noguez-Alcántara, B., Ruiz, J., Pérez-Segura, E., 2007. Geological and metallogenetic characteristics of the porphyry copper deposits of México and their situation in the world context. In: Alaniz-Álvarez, S.A., NietoSamaniego, A.F. (Eds.), Geology of México: Celebrating the Centenary of the Geological Society of México. Geological Society Of America Special Paper 422, pp. $433-458$.

Williams, P., Barton, M.D., Johnson, D.A., Fontboté, L., De Haller, A., Mark, G., Oliver, N.H.S., Marschik, R., 2005. Iron oxide copper-gold deposits: geology, space-time distribution, and possible modes of origin. In: Hedenquist, J.W., Thompson, J.F.H., Goldfarb, R.J., Richards, J.P. (Eds.), Economic Geology 100th Anniversary Volume. Society of Economic Geologists, Littleton CO, pp. 371-406.

York, D., Evensen, N.M., López-Martínez, M., De Basabe-Delgado, J., 2004. Unified equations for the slope, intercept, and standard errors of the best straight line. Am. J. Phys. 73 (3), 367-375. 
Zheng, Y.F., Hoefs, J., 1993. Carbon and oxygen isotope covariations in hydrothermal calcites: theoretical modeling on mixing processes and application to Kushikino gold mining area in Japan. Mineral. Deposita 25, 246-250.

Zürcher, L., Ruiz, J., Barton, M.D., 2001. Paragenesis, elemental distribution, and stable isotopes at the Peñaa Colorada iron skarn, Colima, Mexico. Econ. Geol. 96, 535-557. 


\section{FIGURE CAPTIONS}

Figure 1. Location for the Guaynopa and Guaynopita deposits in Chihuahua. The upper right map was extracted from Fig. 3 in Ferrari et al. (2005), with due permission from the publishers. Lower part: geological maps and representative cross-sections for both mineralized areas. The same colors and symbols are used in all the maps and crosssections for rock units, with the exception of granitic intrusives (red crosses) and late dikes (plain light rose) in the Ki (Lower Cretaceous) assemblage.

Figure 2. Pictures of the ore deposits at Guaynopa and Guaynopita, Chihuahua. (a) Detail of the main IOCG mineralization at Guaynopa from the Tres Amigos manto, featuring magnetite, chalcopyrite and calcite. (b) Fuchsite and calcite in the Guaynopa deposit, from the Tres Amigos manto; fuchsite from this locality was dated at $94.21 \pm 0.71 \mathrm{Ma}$ (Cenomanian) by means of 40Ar/39Ar (see Fig. 7). (c) Stockwork mineralization with patches of argillic alteration (bright colors), IOCG mineralization at Guaynopa, from the La Escondida-El Muerto area. (d) Potassic alteration around quartz veins and veinlets bearing copper mineralization at the Guaynopita porphyry copper deposit, hosted by diorite. Both the fresh diorite and the potassic alteration were dated by means of $\mathrm{U} / \mathrm{Pb}$ in zircons (Fig. 8). (e) Copper mineralization in stockwork, Guaynopita porphyry copper deposit; notice the green staining of the rock due to supergene malachite. Abbreviation: $\mathrm{cc}=$ calcite, $\mathrm{cp}=$ chalcopyrite, $\mathrm{fu}=$ fuchsite, $\mathrm{ma}=$ malachite, $\mathrm{mt}=$ magnetite .

Figure 3. Photomicrographies of representative fluid inclusion assemblages from the Guaynopa IOCG and Guaynopita porphyry copper deposits, Chihuahua. (A) Two-phase aqueous inclusions with homogeneous degree of filling in quartz, Tres Amigos manto, Guaynopa. (B) Two-phase aqueous inclusions with heterogeneous degree of filling in quartz, La Libertad vein, Guaynopa; interpreted as evidence for boiling. (C) $\mathrm{CO}_{2^{-}}$ bearing aqueous inclusions in quartz, La Libertad vein, Guaynopa. (D) Trails of primary and secondary inclusions in vein quartz, Guaynopita. (E) Aqueous inclusion with halite daughter crystal and two more unidentified daughter crystals, Guaynopa. (F) Two-phase aqueous inclusions with heterogeneous degree of filling in quartz, Guaynopita; 
interprtter resemble VMS-type mineralization, and (2) later coarse-grained massive ore assemblages that are mostly composed by pyrrhotite, sphalerite and galena (see Figure $\mathbf{3}$ in Canet et al., 2009), which occur generally in the vicinity of dikes and are associated with late epithermal calcite-quartz veins (plausible skarn-type stages of mineralization). $\mathrm{Zn}-\mathrm{Pb}$ orebodies are associated with host rocks that are largely altered to chlorite and eHistogram for $\delta^{34} \mathrm{~S}$ data of sulfides from the Guaynopa IOCG deposit, Chihuahua.

rite and eHistogram for $\delta^{34} \mathrm{~S}$ data of sulfides from the Guaynopa IOCG deposit, Chihuahua.

Figure 6. Correlation between $\delta^{18} \mathrm{O}$ and $\delta^{13} \mathrm{C}$ values in samples from the Guaynopa IOCG deposit, Chihuahua. Water/rock interaction curves for $\mathrm{W} / \mathrm{R}=20$ and 10 correspond, from left to right, to the followling temperatures: $450^{\circ}, 400^{\circ}, 350^{\circ}, 300^{\circ}$, and $250{ }^{\circ} \mathrm{C}$, which encompass most of the temperatures of homogenization obtained in this study.

Figure 7. Ar/Ar ages for samples of hydrothermalminerals in potassic alteration assemblages from the Guaynopa IOCG deposit, Chihuahua, comprising age spectra, $37 \mathrm{ArCa} / 39 \mathrm{ArK}$ vs. fraction of $39 \mathrm{Ar}$ released, and ${ }^{36} \mathrm{Ar} /{ }^{40} \mathrm{Ar}$ vs. ${ }^{39} \mathrm{Ar} /{ }^{40} \mathrm{Ar}$ correlation diagrams for (A) fuchsite and (B) biotite. The arrows identify the fractions selected to calculate plateau ages that represent $\mathrm{N} 80 \%$ of the ${ }^{39} \mathrm{Ar}$ released. These fractions are in agreement within $1 \sigma$,with a $\mathrm{MSWD}=0.85$ for the weightedmeans. In the age spectra, theweightedmean of the fractions above the arrowwas used to calculate the plateau age. All errors are $1 \sigma$.

Figure 8. Tera-Wasserburg U-Pb concordia plots (a, c, e) and plots of weighted averages of individual $206 \mathrm{~Pb} / 238 \mathrm{U}$ ages $(\mathrm{b}, \mathrm{d}, \mathrm{f})$ of analyzed zircons from a potassic alteration assemblage (sample L-9, diagrams at the bottom) and two granitoid samples (GRANO7, diorite, and CAMP, granodiorite) in the Guaynopita area, Chihuahua, associated with porphyry-type mineralizations. Solid-line ellipses, with black square centers, are data used for age calculations; gray-line ellipses are data excluded from age calculations due to different degrees of $\mathrm{Pb}$-loss and/or zircon inheritance. All $\mathrm{U}-\mathrm{Pb}$ data are plotted with 2-sigma errors and all calculated weighted mean ages are also listed at the 2-sigma level. Original $\mathrm{U}(\mathrm{Th})-\mathrm{Pb}$ data can be found for inspection in Table 4. 
Fig. 1
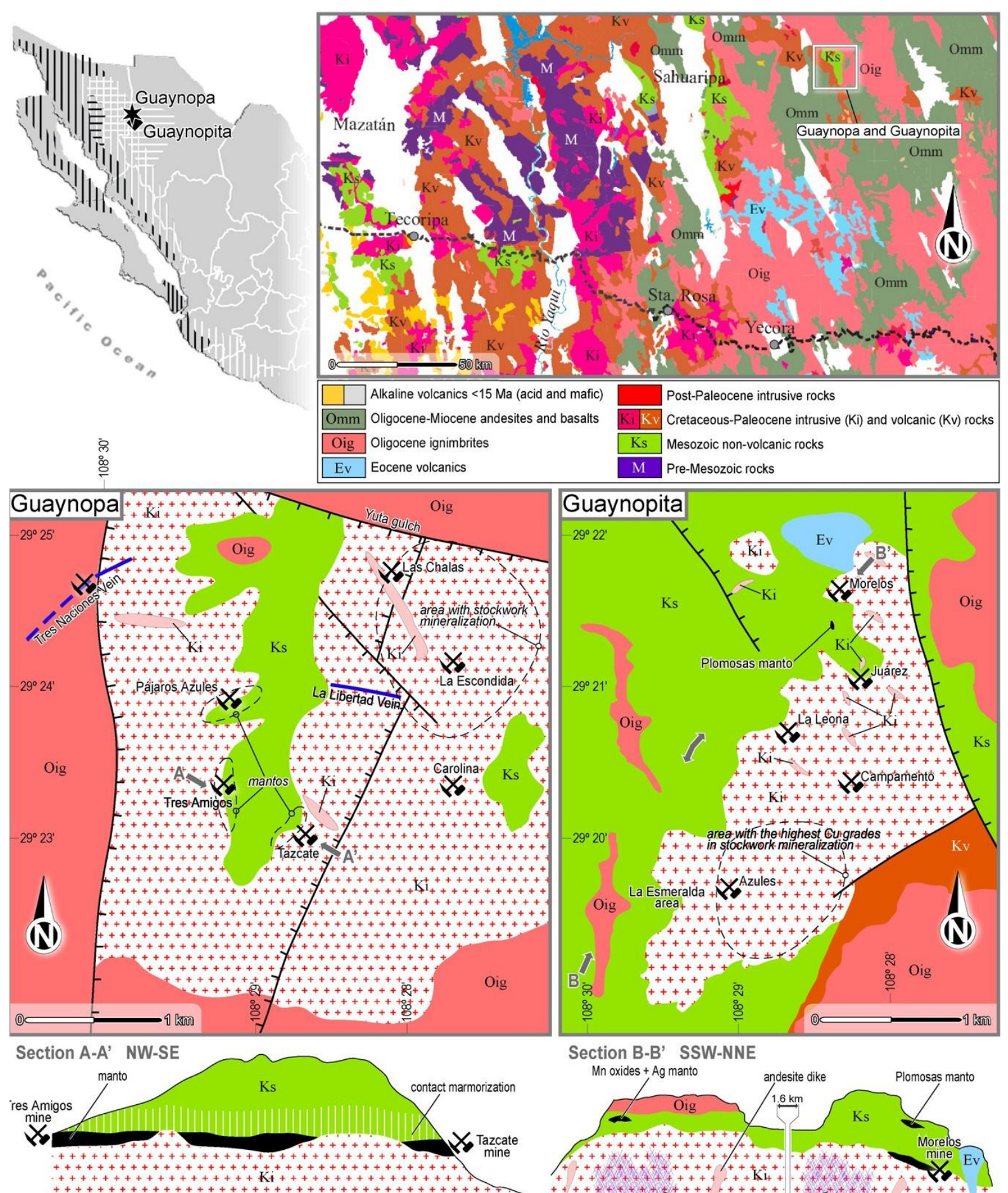

$100 \mathrm{~m}$

(NO VERTICAL EXAGgERATION)

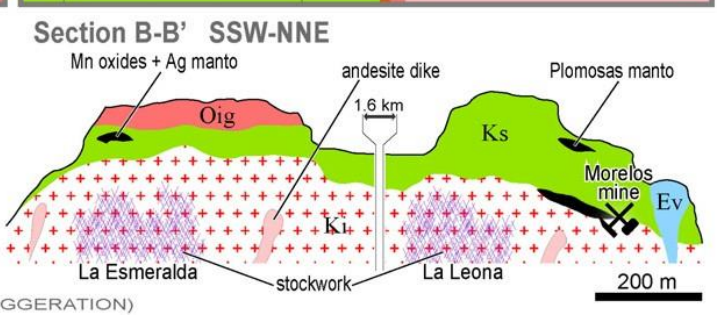


Fig. 2
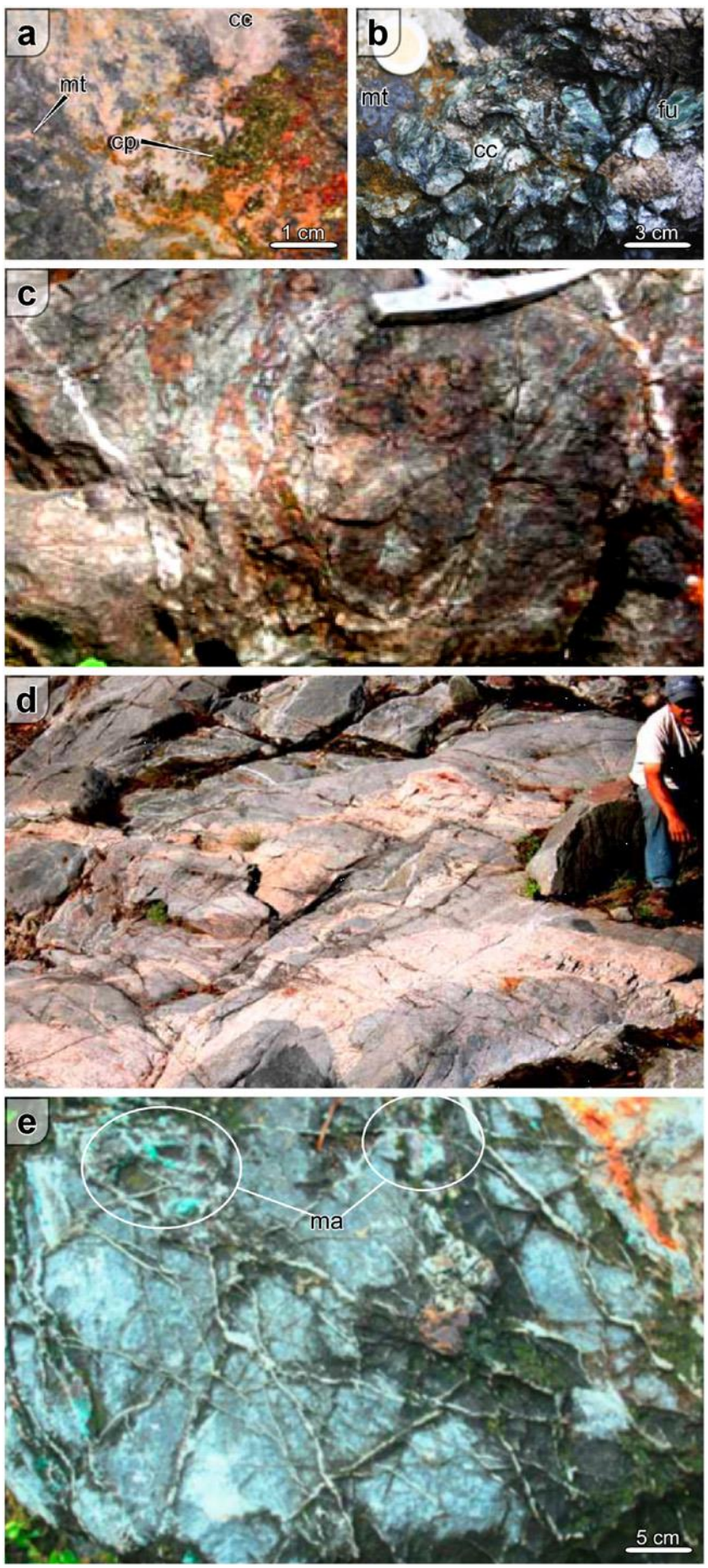
Fig. 3
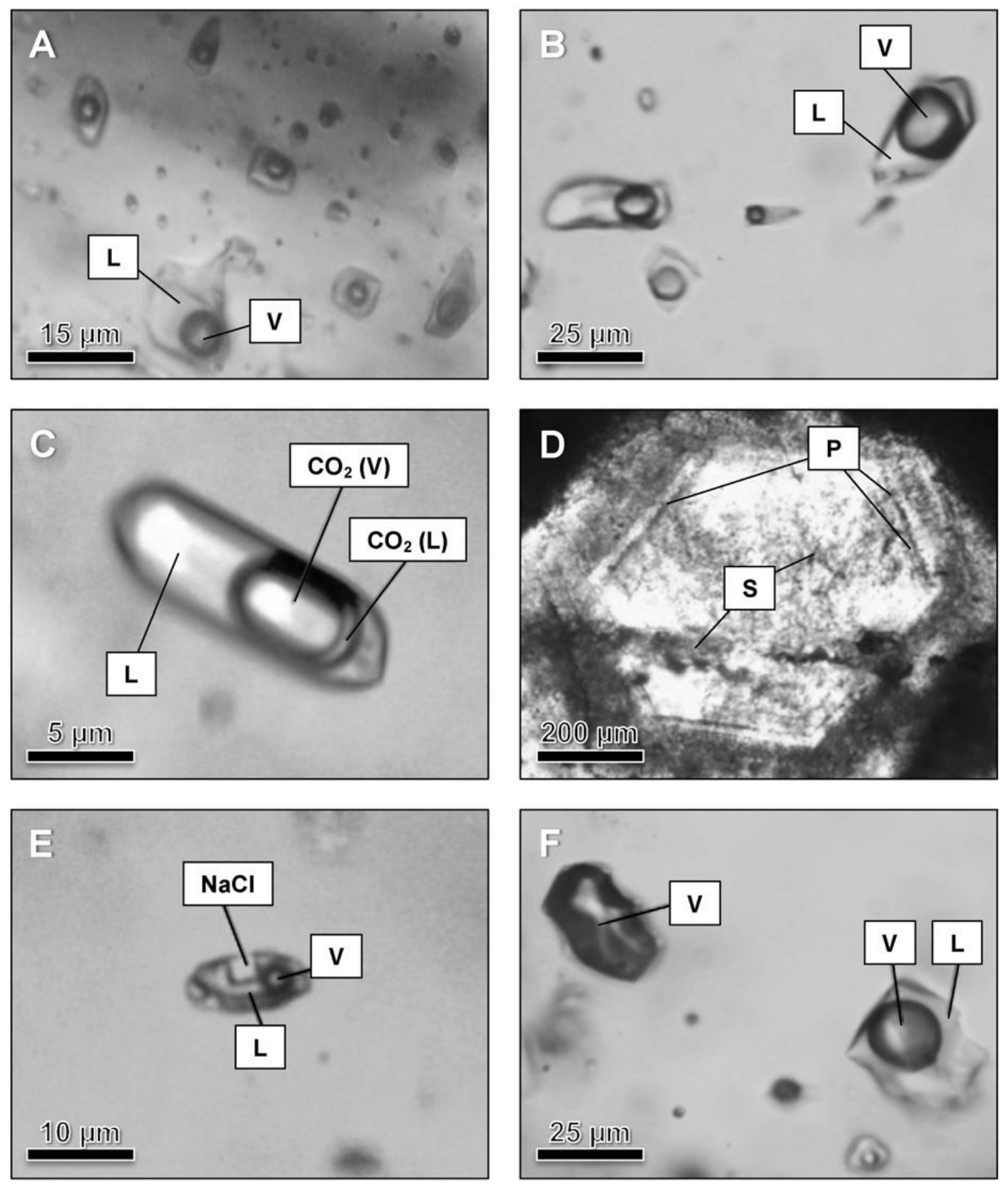
Fig 4

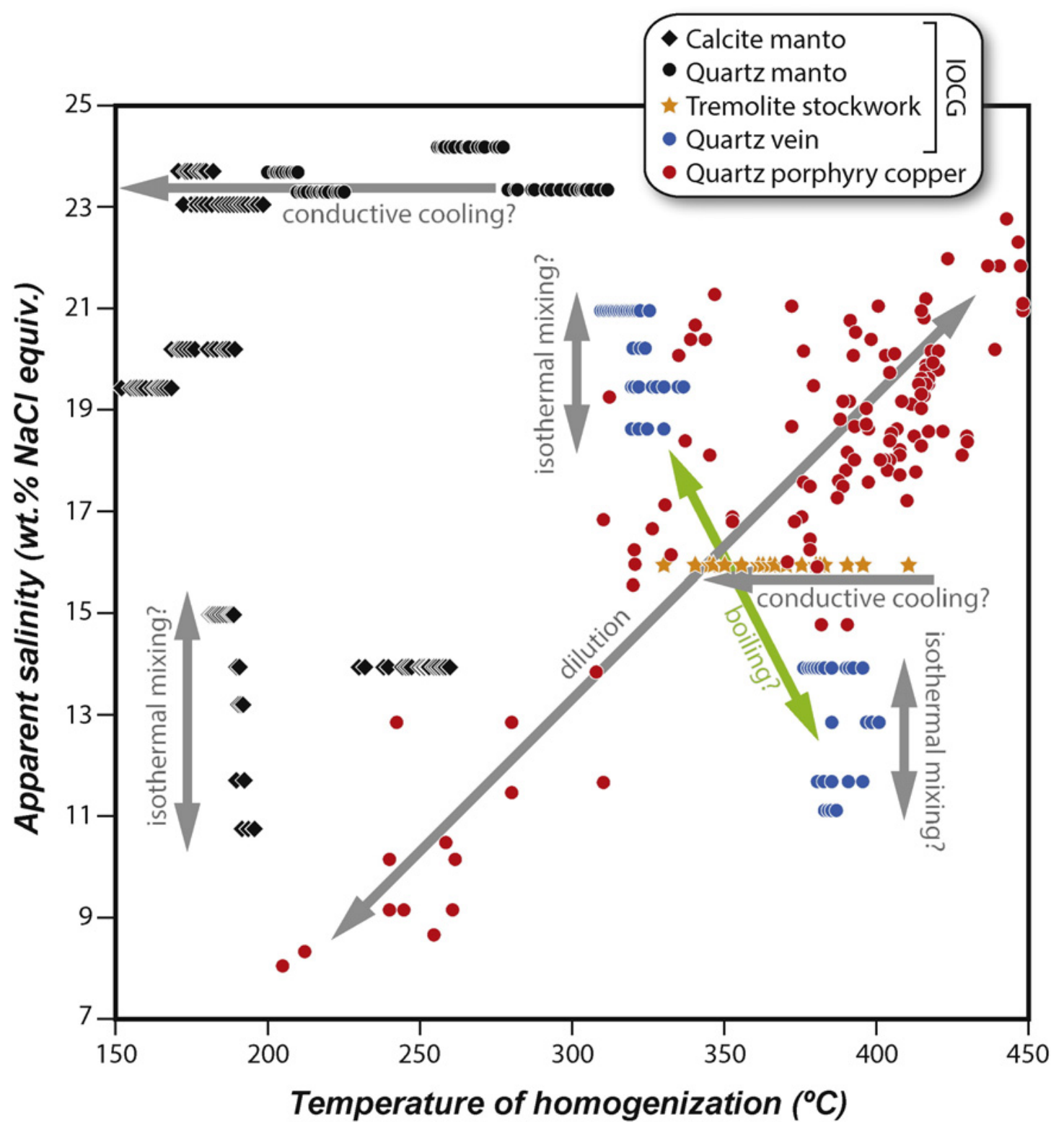


Fig. 5

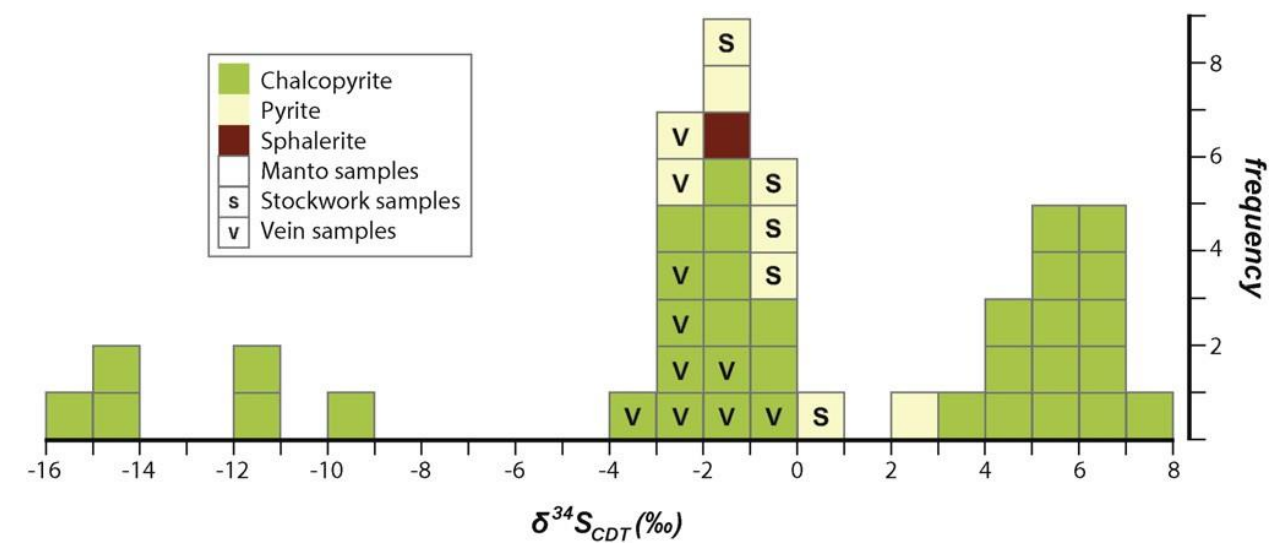

Fig. 6

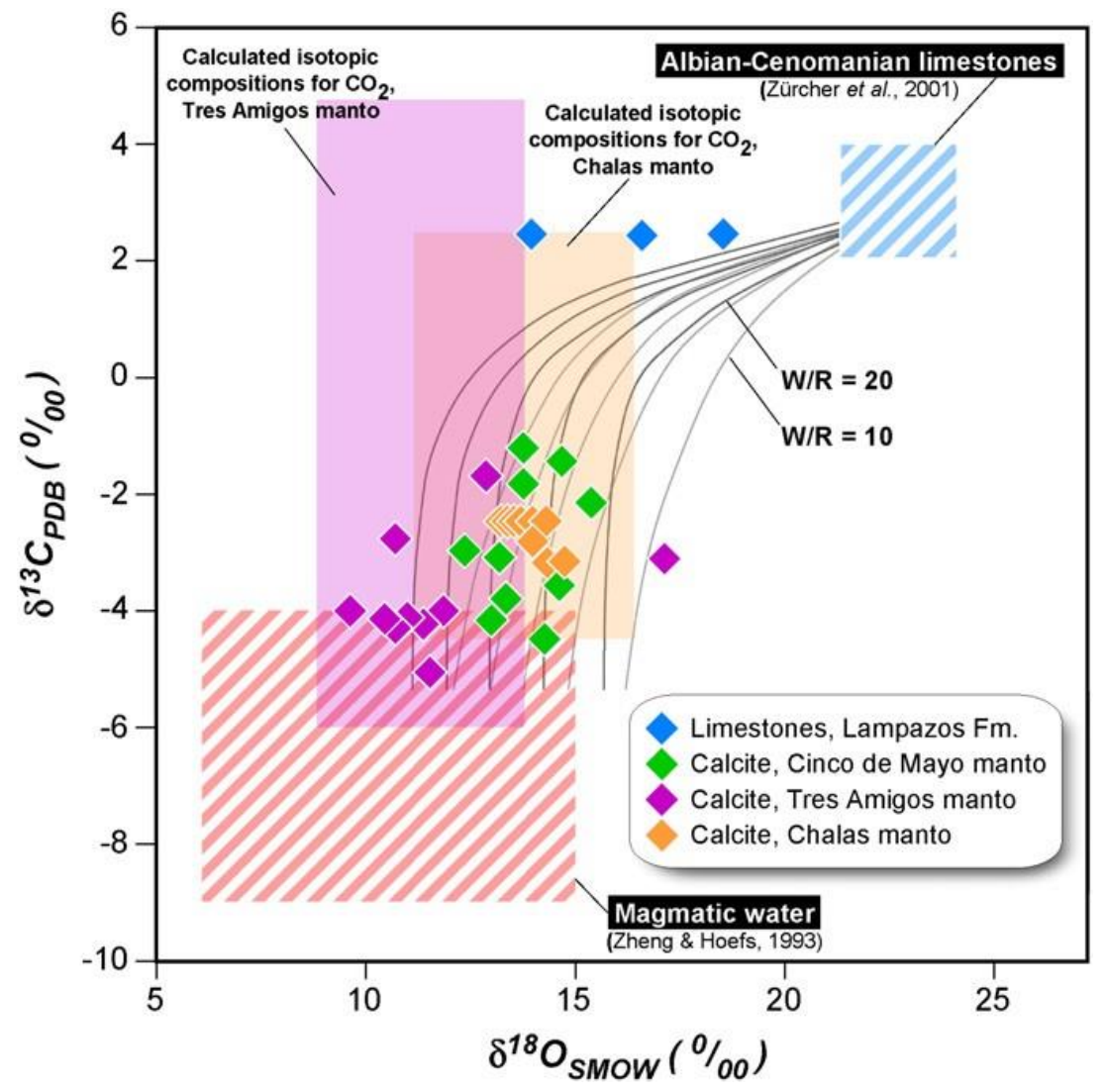


Fig. 7

A
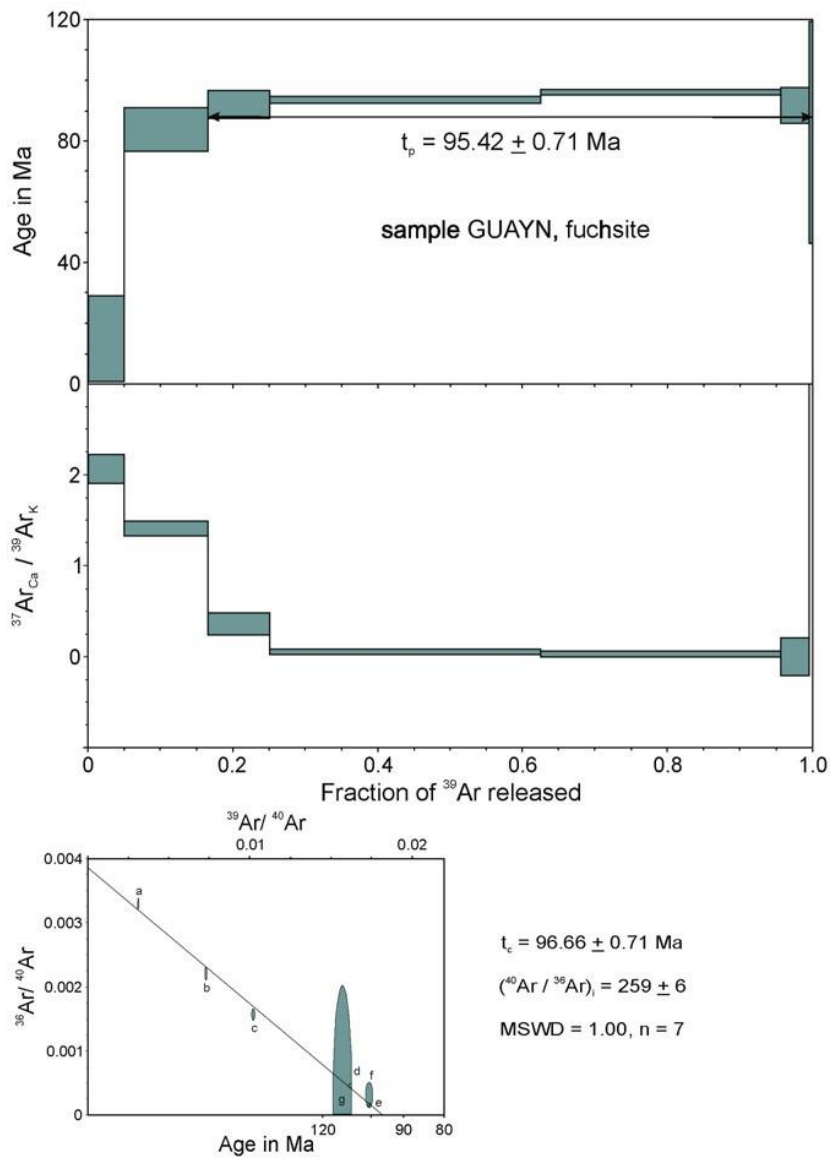

B
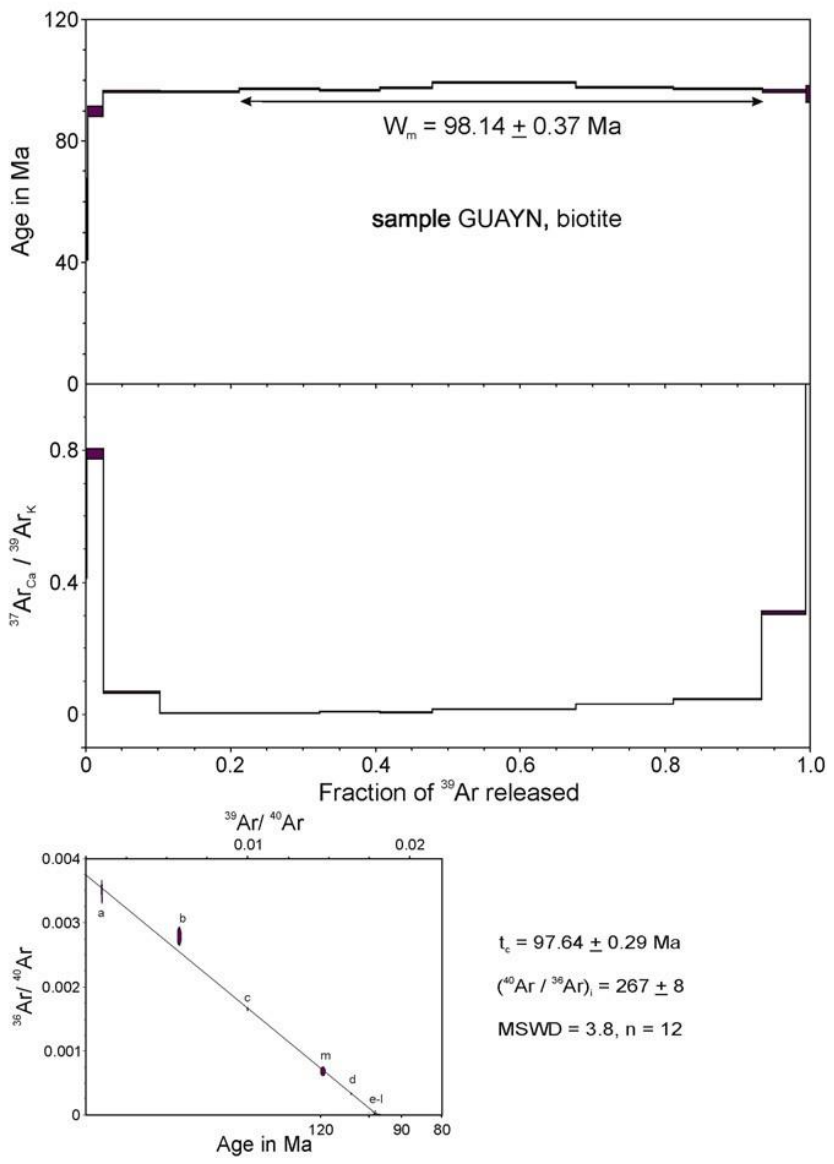

$\mathrm{t}_{\mathrm{c}}=97.64 \pm 0.29 \mathrm{Ma}$

$\left({ }^{40} \mathrm{Ar} /{ }^{30} \mathrm{Ar}\right)_{1}=267 \pm 8$

$M S W D=3.8, n=12$ 
Fig. 8
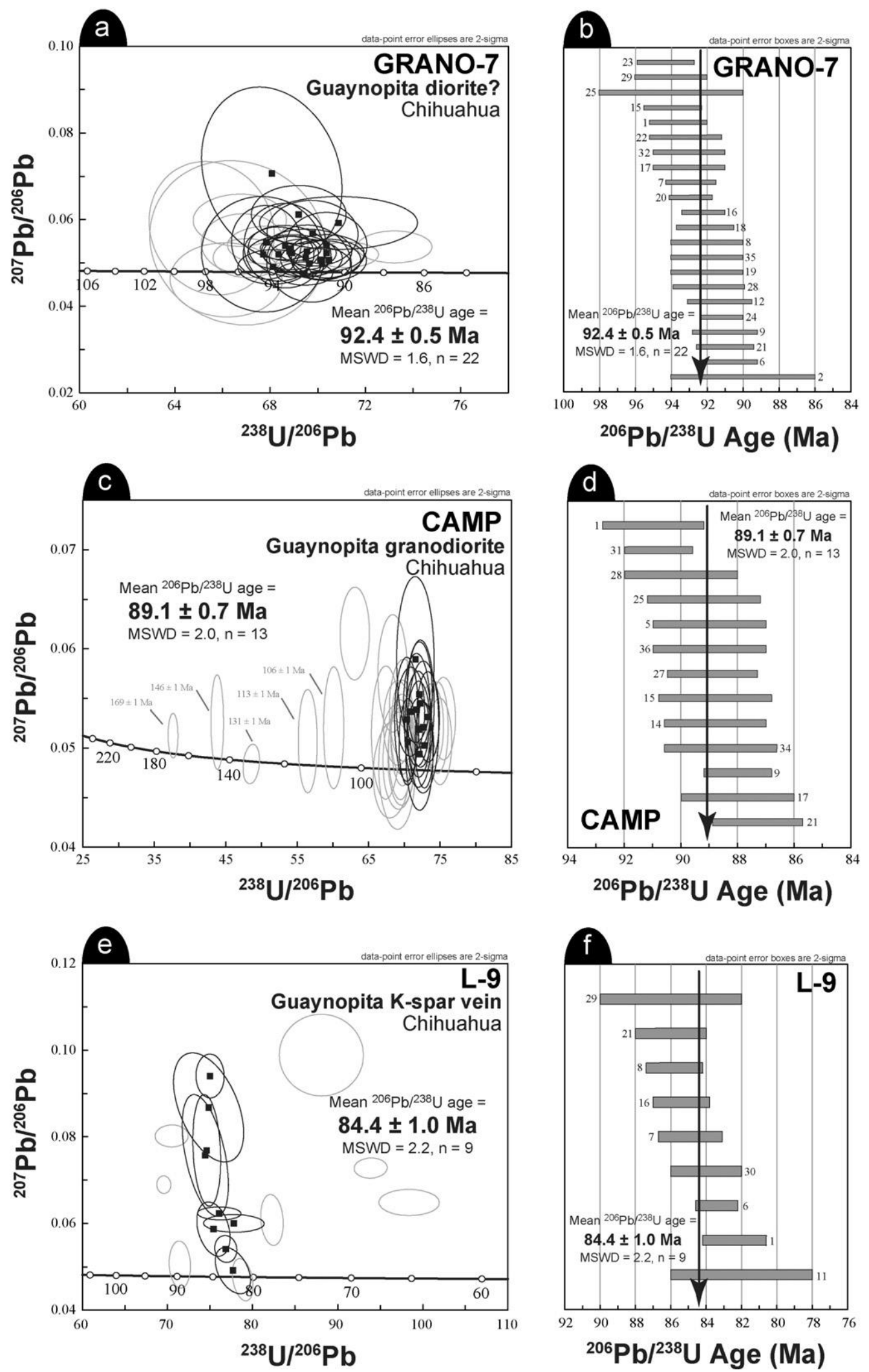


\section{Tables}

\section{Table 1}

\section{Summary of fluid inclusion microthermometric studies in the Guaynopa and Guaynopita}

\section{deposits, Chihuahua.}

\begin{tabular}{|c|c|c|c|c|c|c|c|c|c|c|}
\hline Deposit & Mineral & Ore association & $\begin{array}{l}\text { Th range } \\
\left({ }^{\circ} \mathrm{C}\right)\end{array}$ & $\begin{array}{l}\text { Average Th } \\
\left({ }^{\circ} \mathrm{C}\right)\end{array}$ & $\begin{array}{l}\mathrm{Tm}_{\mathrm{i}} \text { range } \\
\left({ }^{\circ} \mathrm{C}\right)\end{array}$ & $\begin{array}{l}\text { Average } \mathrm{Tm}_{\mathrm{i}} \\
\left({ }^{\circ} \mathrm{C}\right)\end{array}$ & $\begin{array}{l}\text { Salinity for } \mathrm{Tm}_{\mathrm{i}} \text { range } \\
\text { (wt.\% } \mathrm{NaCl} \text { equiv.) }\end{array}$ & $\begin{array}{l}\text { Average salinity } \\
\text { (wt.\% } \mathrm{NaCl} \text { equiv.) }\end{array}$ & $\mathrm{n}$ & Notes \\
\hline \multirow{3}{*}{$\begin{array}{l}\text { Guaynopa } \\
\quad \text { (Las Chalas) Calcite }\end{array}$} & Quartz & IOCG manto & 255 to 310 & 280 & -21.5 to -22.8 & -22.2 & 23.4 to 24.2 & 23.8 & 40 & \\
\hline & Calcite & IOCG manto & 182 to 198 & 171 & -21.0 to -22.0 & -21.5 & 23.1 to 23.7 & 23.4 & 40 & \\
\hline & Calcite & IOCG manto & 184 to 190 & 172 & -21.0 & -21.0 & 23.1 & 23.1 & 26 & \\
\hline \multirow{4}{*}{$\begin{array}{l}\text { Guaynopa Quartz } \\
\text { (Tres Amigos) }\end{array}$} & Quartz & IOCG manto & 230 to 258 & 248 & -10.0 & -10.0 & 13.9 & 13.9 & 20 & \\
\hline & Quartz & IOCG manto & 200 to 225 & 212 & -21.4 to -22.0 & -21.7 & 23.3 to 23.7 & 23.5 & 31 & \\
\hline & Calcite & IOCG manto & 180 to 195 & 189 & -7.2 to -11.0 & -9.2 & 10.7 to 15.0 & 13.0 & 35 & \\
\hline & Calcite & IOCG manto & 152 to 189 & 169 & -16.0 to -17.0 & -16.6 & 19.5 to 20.2 & 19.9 & 39 & \\
\hline \multirow[t]{3}{*}{ Guaynopa (La Libertad) } & Quartz & IOCG vein & 376 to 400 & 385 & -7.5 to -10.1 & -9.3 & 11.1 to 13.9 & 13.1 & 35 & $\mathrm{CO}_{2}$-rich \\
\hline & & Th for $\mathrm{CO}_{2}$ : & 31.2 to 33.5 & 32.7 & & & & & 21 & \\
\hline & Quartz & IOCG vein & 310 to 336 & 321 & -14.0 to -18.1 & -16.6 & 18.6 to 21.0 & 19.9 & 49 & $\begin{array}{l}\text { Evidence } \\
\text { for boiling }\end{array}$ \\
\hline Guaynopa (El Muerto) & Tremolit & IOCG swk. & 330 to 410 & 367 & -12.1 & -12.1 & 16.0 & 16.0 & 30 & \\
\hline \multirow[t]{5}{*}{ Guaynopita (La Esperanza) } & Quartz & porph. Cu swk. & 388 to 439 & 408 & -13.7 to -17.7 & -15.3 & 17.5 to 20.8 & 18.8 & 22 & \\
\hline & Quartz & porph. Cu swk. & 335 to 448 & 388 & -11.9 to -18.5 & -15.5 & 15.9 to 21.3 & 19.0 & 32 & \\
\hline & Quartz & porph. Cu swk. & 330 to 448 & 406 & -10.0 to -18.0 & -14.2 & 13.9 to 21.0 & 17.9 & 37 & \\
\hline & & & 396 to 420 & Ts for $\mathrm{NaCl}$ : & 180 to 380 & & 30.0 to 42.0 & 35.1 & 6 & \\
\hline & Quartz & porph. Cu swk. & 205 to 387 & 292 & -5.2 to -16.0 & -9.7 & 8.1 to 19.5 & 13.4 & 25 & \\
\hline
\end{tabular}

Key: IOCG $=$ iron oxide-copper-gold deposit, $\mathrm{n}=$ number of analyzed inclusions, porph. $\mathrm{Cu}=$ porphyry copper, swk. $=$ stockwork, $\mathrm{Th}=$ temperature of homogenization, $\mathrm{Tm}_{\mathrm{i}}=$ temperature of ice melting; $\mathrm{Ts}=$ temperature of halite solubilization. 


\section{Table 2}

Sulfur isotope compositions in sulfides in the Guaynopa IOCG deposits, Chihuahua.

\begin{tabular}{|c|c|c|c|}
\hline Ore body & Assemblage & Mineral & $\delta^{34} \mathrm{~S}(\%$ ) \\
\hline \multirow{8}{*}{ Tres Amigos } & \multirow{8}{*}{ Manto } & Chalcopyrite & -11.6 \\
\hline & & chalcopyrite & -11.4 \\
\hline & & Chalcopyrite & -15.1 \\
\hline & & Chalcopyrite & -14.5 \\
\hline & & Chalcopyrite & -14.0 \\
\hline & & Chalcopyrite & -0.1 \\
\hline & & Chalcopyrite & -9.8 \\
\hline & & Chalcopyrite & -0.1 \\
\hline Tazcate & Manto & Pyrite & -1.1 \\
\hline \multirow{11}{*}{ Chalas } & \multirow{11}{*}{ Manto } & Sphalerite & -1.2 \\
\hline & & Chalcopyrite & -1.3 \\
\hline & & Chalcopyrite & -2.5 \\
\hline & & Chalcopyrite & -1.8 \\
\hline & & Chalcopyrite & -1.8 \\
\hline & & Chalcopyrite & -1.5 \\
\hline & & Chalcopvrite & 6.0 \\
\hline & & Chalcopyrite & 5.8 \\
\hline & & Chalcopyrite & 7.0 \\
\hline & & Chalcopyrite & 6.1 \\
\hline & & Chalcopyrite & 6.7 \\
\hline \multirow[t]{16}{*}{ Cinco de Mayo } & \multirow[t]{16}{*}{ Manto } & Chalcopyrite & 3.5 \\
\hline & & Chalcopyrite & 5.0 \\
\hline & & Chalcopyrite & 6.5 \\
\hline & & Chalcopyrite & 5.5 \\
\hline & & Chalcopyrite & 6.8 \\
\hline & & Chalcopyrite & 5.5 \\
\hline & & Chalcopyrite & 4.2 \\
\hline & & Chalcopyrite & 5.0 \\
\hline & & Chalcopyrite & 4.9 \\
\hline & & Chalcopyrite & 4.6 \\
\hline & & Pyrite & 0.2 \\
\hline & & Pyrite & -0.9 \\
\hline & & Pyrite & -0.9 \\
\hline & & Pyrite & -0.8 \\
\hline & & Pyrite & -1.6 \\
\hline & & Chalcopyrite & -0.2 \\
\hline \multirow[t]{2}{*}{ La Escondida } & \multirow[t]{2}{*}{ Stockwork } & Chalcopyrite & -2.5 \\
\hline & & Chalcopyrite & \\
\hline \multirow[t]{7}{*}{ La Libertad } & \multirow[t]{7}{*}{ Vein } & Chalcopyrite & -1.9 \\
\hline & & Chalcopyrite & -2.0 \\
\hline & & Chalcopyrite & -2.6 \\
\hline & & Chalcopyrite & -2.4 \\
\hline & & Chalcopyrite & -3.7 \\
\hline & & Pyrite & -1.6 \\
\hline & & Pyrite & -2.3 \\
\hline
\end{tabular}




\section{Table 3}

\section{$\mathrm{O}$ and $\mathrm{C}$ isotope compositions in carbonates, and water and $\mathrm{CO}_{2}$ in isotopic equilibrium}

\section{with them, in the Guaynopa IOCG deposits, Chihuahua.}

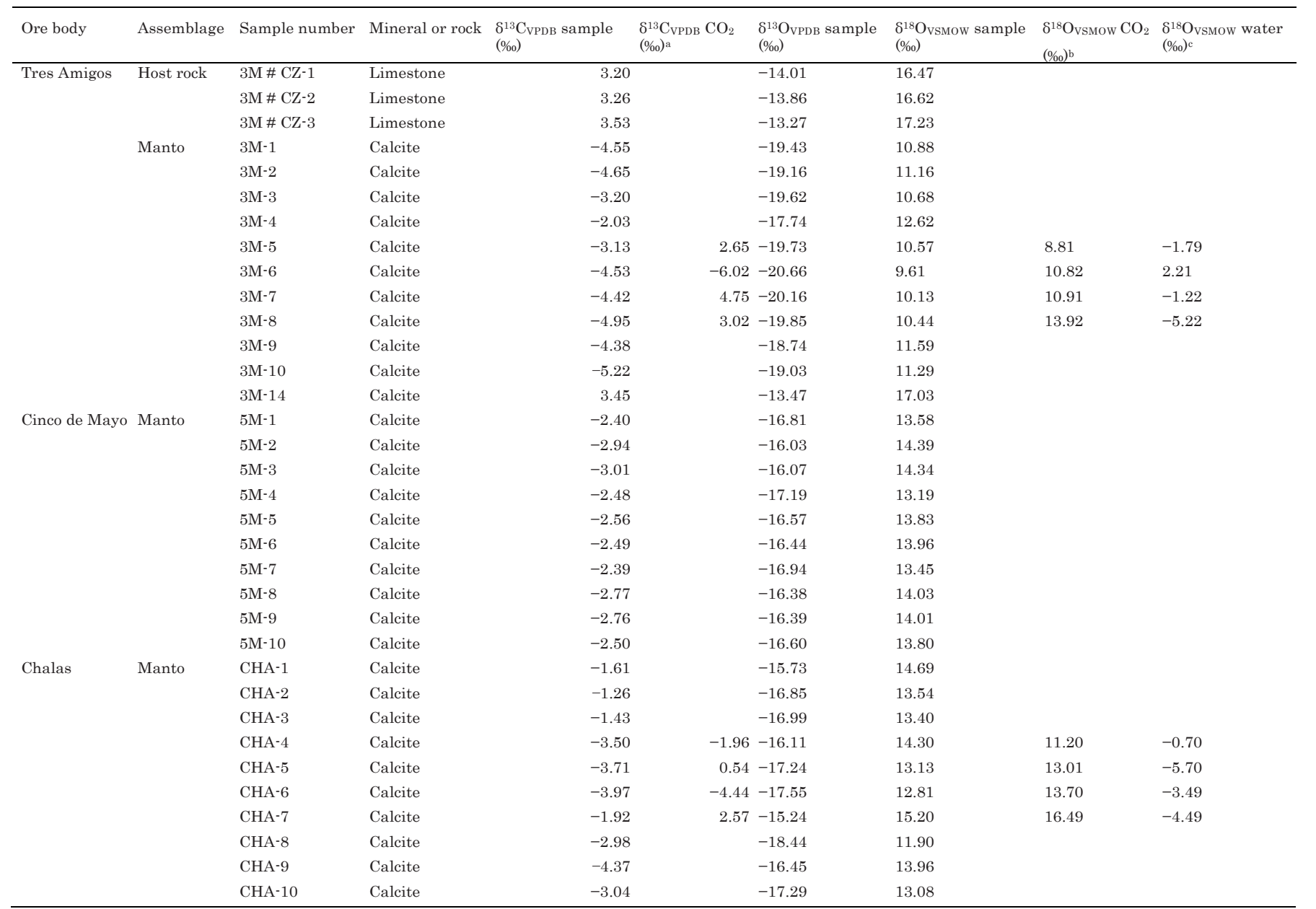

For these calculations we used:

(1) the highest and lowest average temperatures of homogenization (Th) of fluid inclusions in each manto (see Table 1); these are $169^{\circ}$ and $248{ }^{\circ} \mathrm{C}$ for the Tres Amigos manto, and $171^{\circ}$ and $280^{\circ} \mathrm{C}$ for the Chalas manto;

(2) the highest and lowest isotopic values for $\delta 13 \mathrm{C}$ and $\delta 18 \mathrm{O}$ in each manto where Th are available, which are highlighted in bold typeface.

a Calculated by using the fractionation equation of Bottinga (1969) and Ohmoto and Rye (1979).

b Calculated by using the fractionation equation of Ohmoto and Rye (1979).

c Calculated by using the fractionation equation of Horita (2014). 


\section{Table 4}

Summary of ${ }^{40} \mathrm{Ar} /{ }^{39} \mathrm{Ar}$ results for sample GUAYN-1, which corresponds to a potassic alteration assemblage fromthe Guaynopa IOCG deposit, Chihuahua, Mexico. Latitude $28.4952^{\circ} \mathrm{N}$, longitude $108.5109^{\circ} \mathrm{W}$.

\begin{tabular}{|c|c|c|c|c|c|c|c|c|c|c|c|}
\hline$P_{W r}$ & $F^{39} A r$ & ${ }^{40} A{ }^{* *}{ }^{39}{ }^{A r_{K}}$ & $t(\mathrm{Ma})$ & $\%{ }^{40} A r^{*}$ & ${ }^{40} A r \beta^{36} A r$ & ${ }^{37}{ }_{A r_{C a}}{ }^{39} A r_{k} K$ & $t_{i}(\mathrm{Ma})$ & $t_{p}(\mathrm{Ma})$ & $t_{c}(\mathrm{Ma})$ & $\left({ }^{40} A r{ }^{36} A r\right)_{i}$ & $M S W D / n$ \\
\hline \multicolumn{12}{|c|}{ Fuchsite (chromian muscovite) } \\
\hline 0.70 & 0.0502 & $2.47 \pm 2.31$ & $14.84 \pm 13.86$ & 2.59 & 303.35 & 2.065 & & & & & \\
\hline 1.20 & 0.1156 & $14.10 \pm 1.25$ & $83.16 \pm 7.19$ & 34.78 & 453.07 & 1.406 & & & & & \\
\hline 1.60 & 0.0851 & $15.52 \pm 0.80$ & $91.37 \pm 4.58$ & 53.68 & 637.95 & 0.362 & & & & & \\
\hline 2.10 & 0.3743 & $15.78 \pm 0.20$ & $92.86 \pm 1.15$ & 86.60 & 2205.43 & 0.055 & & & & & \\
\hline 2.70 & 0.3306 & $16.21 \pm 0.16$ & $95.29 \pm 0.92$ & 95.46 & 6510.95 & 0.031 & & & & & \\
\hline 3.30 & 0.0398 & $15.44 \pm 1.02$ & $90.91 \pm 5.86$ & 99.99 & 3240.62 & b0.001 & & & & & \\
\hline 4.50 & 0.0044 & $17.09 \pm 9.53$ & $100.30 \pm 54.45$ & 91.04 & 3296.52 & 5.015 & $88.54 \pm 1.33$ & $94.21 \pm 0.71$ & $94.96 \pm 0.79$ & $273 \pm 11$ & $0.55 / 6$ \\
\hline \multicolumn{12}{|l|}{ Biotite } \\
\hline 0.20 & 0.0003 & $-8.38 \pm 17.22$ & $-52.42 \pm 109.31$ & -2.81 & 287.44 & 0.032 & & & & & \\
\hline 0.60 & 0.0019 & $8.97 \pm 2.25$ & $54.48 \pm 13.45$ & 17.65 & 358.85 & 0.449 & & & & & \\
\hline 1.20 & 0.0221 & $15.00 \pm 0.27$ & $90.22 \pm 1.60$ & 51.15 & 604.94 & 0.788 & & & & & \\
\hline 1.80 & 0.0780 & $16.12 \pm 0.07$ & $96.78 \pm 0.43$ & 90.28 & 3041.18 & 0.068 & & & & & \\
\hline 2.40 & 0.1092 & $16.08 \pm 0.04$ & $96.52 \pm 0.26$ & 98.20 & $16,403.37$ & 0.004 & & & & & \\
\hline 3.00 & 0.1109 & $16.28 \pm 0.05$ & $97.69 \pm 0.29$ & 98.68 & $22,388.11$ & 0.004 & & & & & \\
\hline 3.50 & 0.0833 & $16.19 \pm 0.05$ & $97.18 \pm 0.28$ & 99.17 & $35,437.39$ & 0.009 & & & & & \\
\hline 4.00 & 0.0727 & $16.32 \pm 0.05$ & $97.95 \pm 0.27$ & 99.36 & $46,290.84$ & 0.006 & & & & & \\
\hline 4.60 & 0.1982 & $16.64 \pm 0.04$ & $99.79 \pm 0.25$ & 99.23 & $38,500.68$ & 0.016 & & & & & \\
\hline 6.20 & 0.1344 & $16.37 \pm 0.04$ & $98.22 \pm 0.22$ & 99.57 & $68,271.26$ & 0.031 & & & & & \\
\hline 7.20 & 0.1224 & $16.28 \pm 0.04$ & $97.69 \pm 0.22$ & 99.91 & $322,974.07$ & 0.046 & & & & & \\
\hline 8.50 & 0.0606 & $16.13 \pm 0.07$ & $96.85 \pm 0.43$ & 99.87 & $230,720.98$ & 0.310 & & & & & \\
\hline 13.00 & 0.0060 & $15.99 \pm 0.48$ & $96.00 \pm 2.78$ & 79.97 & 1475.46 & 2.448 & $97.61 \pm 0.27$ & $97.64 \pm 0.29$ & $97.64 \pm 0.29$ & $267 \pm 8$ & $3.8 / 12$ \\
\hline
\end{tabular}


Table 5

$\mathrm{U}-\mathrm{Th}-\mathrm{Pb}$ zircon data for Guaynopita samples (porphyry copper deposit), Chihuahua, Mexico.

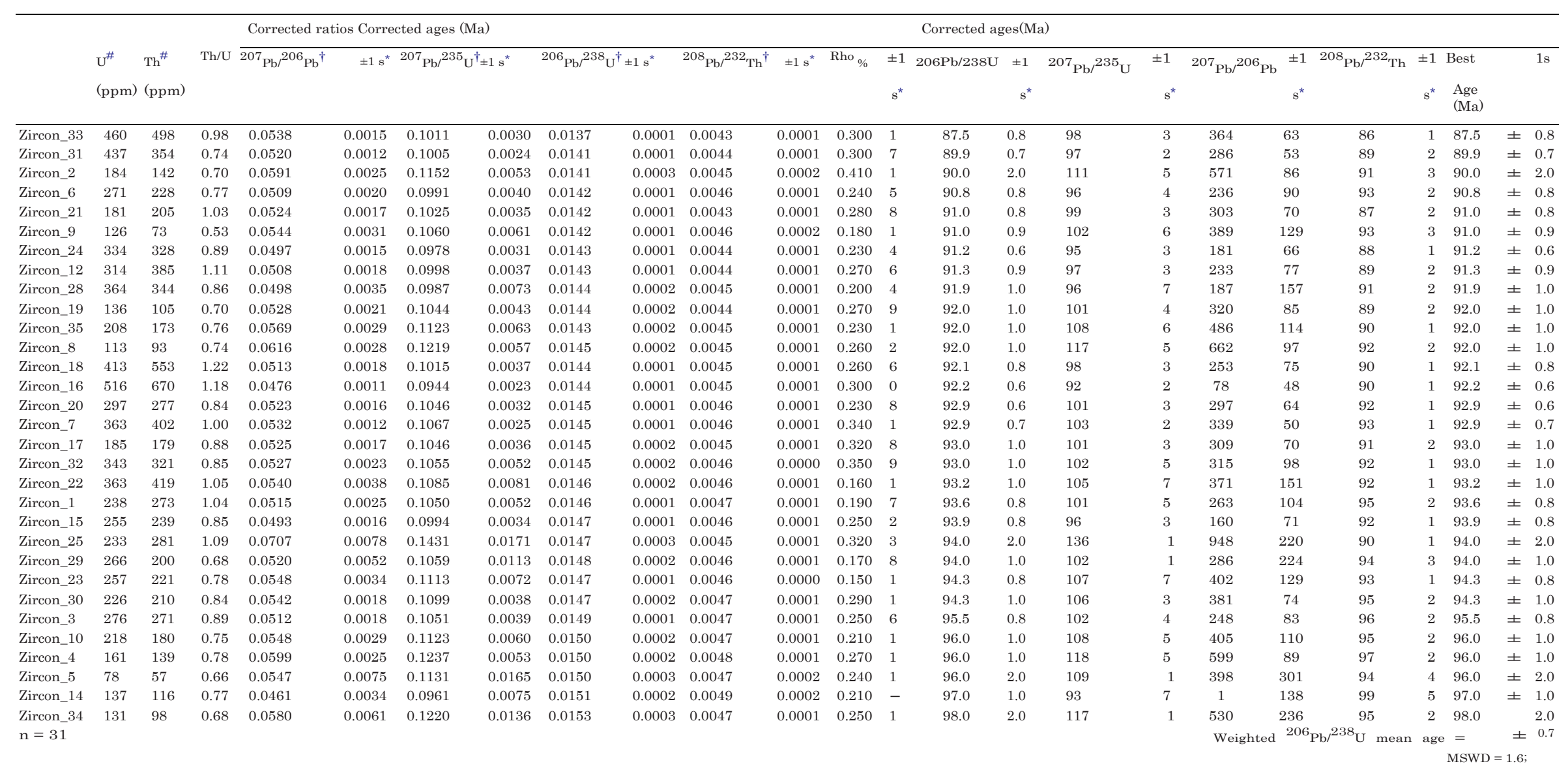

$\mathrm{n}=22$ 
Sample CAMP Mount ICGEO-20 (January 2011)

\begin{tabular}{|c|c|c|c|c|c|c|c|c|c|c|c|c|c|c|c|c|c|c|c|c|c|c|c|}
\hline Zircon_18 & 438 & 207 & 0.43 & 0.0529 & 0.0017 & 0.0968 & 0.0032 & 0.0133 & 0.0001 & 0.0043 & 0.0001 & 0.280 & 10 & 84.9 & 0.8 & 94 & 3 & 325 & 72 & 87 & 2 & 84.9 & \pm 0. \\
\hline Zircon_32 & 272 & 230 & 0.77 & 0.0508 & 0.0018 & 0.0932 & 0.0034 & 0.0133 & 0.0001 & 0.0041 & 0.0001 & 0.260 & 5 & 85.4 & 0.8 & 90 & 3 & 232 & 80 & 83 & 2 & 85.4 & \pm 0 . \\
\hline Zircon_13 & 301 & 220 & 0.67 & 0.0520 & 0.0019 & 0.0962 & 0.0036 & 0.0134 & 0.0001 & 0.0040 & 0.0001 & 0.220 & 8 & 85.8 & 0.7 & 93 & 3 & 284 & 82 & 80 & 2 & 85.8 & \pm 0. \\
\hline Zircon_26 & 233 & 129 & 0.50 & 0.0521 & 0.0017 & 0.0977 & 0.0034 & 0.0136 & 0.0001 & 0.0044 & 0.0001 & 0.280 & 9 & 86.8 & 0.8 & 95 & 3 & 290 & 75 & 89 & 2 & 86.8 & \pm 0. \\
\hline Zircon_21 & 245 & 178 & 0.66 & 0.0530 & 0.0019 & 0.1000 & 0.0036 & 0.0136 & 0.0001 & 0.0040 & 0.0001 & 0.270 & 10 & 87.3 & 0.8 & 97 & 3 & 328 & 79 & 81 & 2 & 87.3 & \pm \\
\hline Zircon_17 & 178 & 102 & 0.52 & 0.0523 & 0.0027 & 0.0990 & 0.0053 & 0.0138 & 0.0002 & 0.0042 & 0.0001 & 0.220 & 8 & 88.0 & 1.0 & 96 & 5 & 299 & 118 & 85 & 2 & 88.0 & \pm 1 . \\
\hline Zircon_9 & 292 & 168 & 0.52 & 0.0504 & 0.0018 & 0.0953 & 0.0034 & 0.0137 & 0.0001 & 0.0042 & 0.0001 & 0.220 & 4 & 88.0 & 0.6 & 92 & 3 & 214 & 82 & 85 & 2 & 88.0 & \pm 0 . \\
\hline Zircon_34 & 195 & 111 & 0.52 & 0.0546 & 0.0026 & 0.1040 & 0.0051 & 0.0138 & 0.0002 & 0.0045 & 0.0001 & 0.230 & 11 & 88.6 & 1.0 & 100 & 5 & 397 & 110 & 91 & 3 & 88.6 & \pm \\
\hline Zircon_14 & 272 & 198 & 0.66 & 0.0554 & 0.0022 & 0.1060 & 0.0043 & 0.0139 & 0.0001 & 0.0043 & 0.0001 & 0.240 & 13 & 88.8 & 0.9 & 102 & 4 & 428 & 87 & 87 & 2 & 88.8 & \pm \\
\hline Zircon_15 & 194 & 114 & 0.54 & 0.0493 & 0.0023 & 0.0945 & 0.0046 & 0.0139 & 0.0002 & 0.0041 & 0.0001 & 0.240 & 3 & 88.8 & 1.0 & 92 & 4 & 160 & 106 & 82 & 2 & 88.8 & \pm \\
\hline Zircon_27 & 206 & 119 & 0.53 & 0.0519 & 0.0020 & 0.0994 & 0.0039 & 0.0139 & 0.0001 & 0.0045 & 0.0001 & 0.240 & 7 & 88.9 & 0.8 & 96 & 4 & 279 & 87 & 90 & 2 & 88.9 & \pm \\
\hline Zircon_36 & 149 & 79 & 0.48 & 0.0518 & 0.0024 & 0.0995 & 0.0047 & 0.0139 & 0.0002 & 0.0045 & 0.0001 & 0.230 & 7 & 89.0 & 1.0 & 96 & 4 & 276 & 107 & 90 & 2 & 89.0 & \pm \\
\hline Zircon_5 & 160 & 85 & 0.49 & 0.0587 & 0.0034 & 0.1136 & 0.0068 & 0.0140 & 0.0002 & 0.0046 & 0.0002 & 0.260 & 18 & 89.0 & 1.0 & 109 & 6 & 555 & 130 & 93 & 4 & 89.0 & \pm \\
\hline Zircon_25 & 175 & 86 & 0.45 & 0.0538 & 0.0023 & 0.1035 & 0.0046 & 0.0139 & 0.0002 & 0.0044 & 0.0001 & 0.260 & 11 & 89.2 & 1.0 & 100 & 4 & 362 & 96 & 89 & 3 & 89.2 & \pm \\
\hline
\end{tabular}

(continued on next page) 


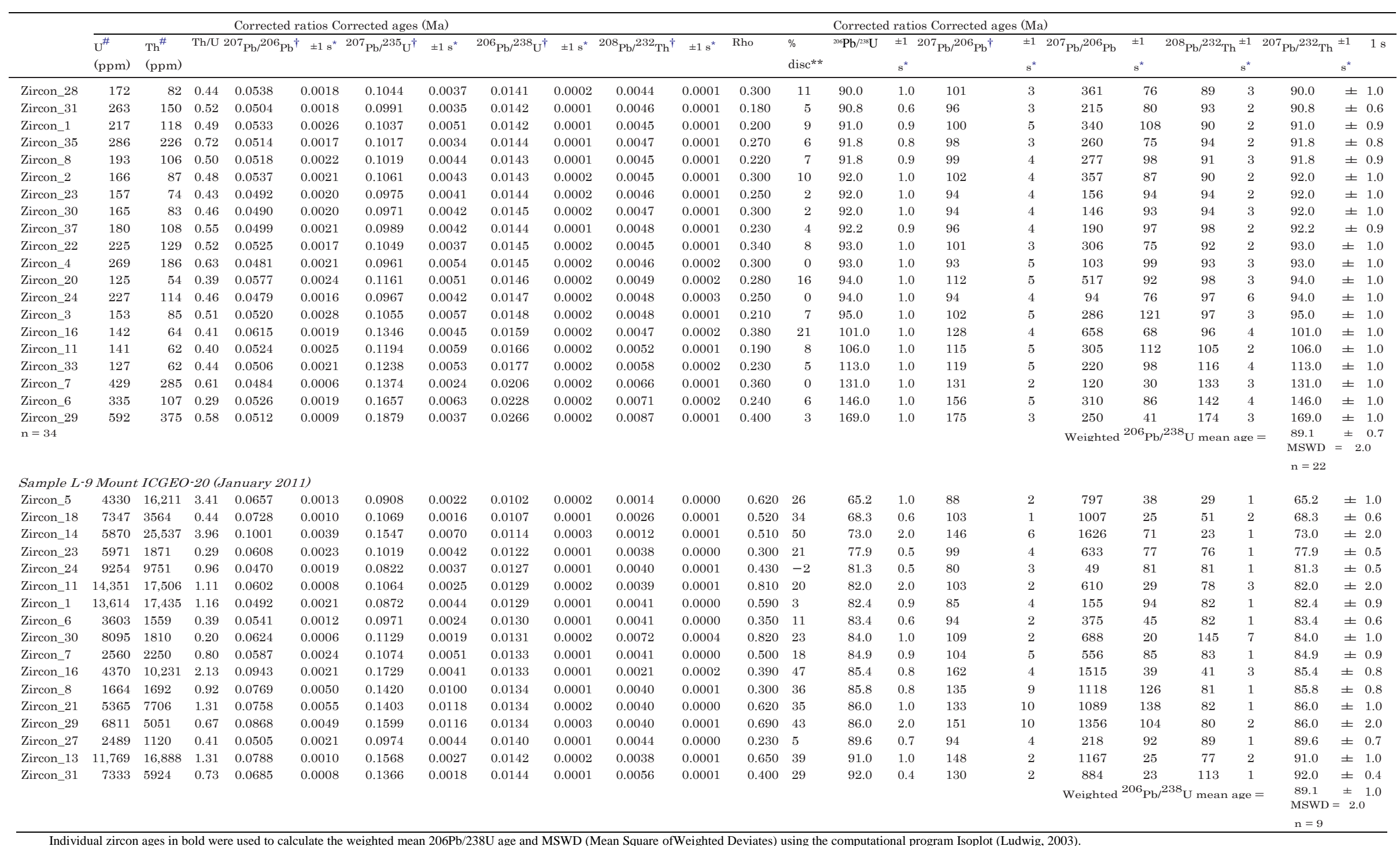

Individual zircon ages in bold were used to calculate the weighted mean 206Pb/238U age and MSWD (Mean Sq
\# U and Th concentrations ( $\mathrm{ppm}$ ) are calculated relative to analyses of trace-element glass standard NIST 612 . 
† Isotopic ratios are corrected relative to PLE standard zircon for mass bias and down-hole fractionation (PLE, Plešovice = 337 Ma; Sláma et al., 2008). Common Pb corrections were made using the Andersen Method (Andersen, 2002). All errors in isotopic ratios and ages are absolute and given at the 1-sigma level except for theWeighted Mean $206 \mathrm{~Pb} / 238 \mathrm{U}$ age that is reported at the 2-sigma level.

Percentage discordance obtained using the following equation $(100 *[$ (age $207 \mathrm{~Pb} / 235 \mathrm{U})-($ age $206 \mathrm{~Pb} / 238 \mathrm{U})] /$ age $207 \mathrm{~Pb} / 235 \mathrm{U})$. Positive and negative values indicate normal and inverse discordance, respectively. 